\title{
Fæðingar- og foreldraorlof: Aðdragandi, breytingar og árangur laga sem er ætlað að stuðla að orlofstöku beggja foreldra
}

\author{
Ásdís A. Arnalds, nýdoktor, Félagsráđgjafardeild Háskóla Íslands \\ Guðný Björk Eydal, prófessor, Félagsráđgjafardeild Háskóla Íslands \\ Ingólfur V. Gíslason, prófessor, Félagsfræđi-, mannfræđi- og pjóðfræđi- \\ deild Háskóla Íslands
}

\begin{abstract}
Útdráttur
Í maí 2000 sampykkti Alpingi einróma lög nr. 95/2000 um fæðingar- og foreldraorlof. Lögin fólu í sér afar róttækar breytingar á aðstæðum nýbakaðra foreldra. Samkvæmt markmiðum laganna áttu pau að stuðla að pví að börn nytu samvista við foreldra sína og auðvelda konum og körlum að sampætta atvinnuog fjölskyldulíf. Pessi lög voru í gildi par til heildarendurskoðun leiddi til laga nr. 144/2020. Í pessari grein er spurt að hvaða leyti löggjöfin hafi náð hinu tvípætta markmiði. Gögn, sem aflað með könnunum meðal foreldra á fjórum tímapunktum yfir tæplega 20 ára tímabil, voru nýtt til að greina breytingar á pátttöku mæðra og feðra í umönnun fyrsta barns og breytingar á vinnumarkaðspátttöku mæðra og feðra ári fyrir fæðingu barnsins og par til pað nær priggja ára aldri. Niðurstöður sýna að frá gildistöku laganna hafa feður aukið pátttöku sína í umönnun barna sinna og dregið hefur saman með foreldrum hvað varðar atvinnupátttöku og vinnutíma.
\end{abstract}

Efnisorð: Fæðingarorlof; kynjajafnrétti; atvinnupátttaka; umönnun barna; lagabreytingar. 


\title{
Maternity, paternity, and parental leave: Origin, changes, and impact of a law that aims at encouraging leave use of both parents
}

\begin{abstract}
In May 2000 the Icelandic parliament unanimously voted in favour of a new law on paid parental leave, involving radical changes for parents. The twofold aim of the law was to ensure that children received care from both parents and to enable both men and women to combine family life and participation in the labour market. The law was in effect until a total revision let to a new law being adopted in 2020, though with the same twofold goal. In this article we ask if the goals have been reached. Data collected with four surveys among first-time parents, over a 20 -year period, were analysed to identify changes in the care participation of mothers and fathers and the development in parents' labour market participation a year before birth of their first child until it reaches the age of three. Results show that since the introduction of the law, fathers have increased their participation in care for their children and that the gap in parents' labour market participation and working hours has narrowed.
\end{abstract}

Keywords: Parental leave; gender equality; labour market participation; care of children; law revision.

\section{Inngangur}

Velferðarríki Norðurlanda eru oft talin sambærileg par sem pau leggja áherslu á jöfnuð og að hið opinbera axli ábyrgð á almennu félags- og heilbrigðiskerfi með bótum og niðurgreiðslum (Esping-Andersen 1990; Ólafsson, Daly, Palme \& Kangas 2019). Áhersla á jafnrétti kynja hefur einnig einkennt löndin öll (Eydal, Rostgaaard \& Hiilamo 2018; Thévenon 2011) meðal annars með niðurgreiddri umönnun ungra barna og fæðingarorlofi með háum tekjutengdum bótum sem hvort tveggja ýtir undir vinnumarkaðspátttöku kvenna (Ellingsæter \& Leira 2006; Eydal \& Rostgaard 2012).

Öll löndin hafa pó strítt við viðvarandi mun á stöðu og möguleikum karla og kvenna, ekki hvað síst sökum fjölskylduábyrgðar mæðra. Рað gildir almennt um hinn vestræna heim að barneignir er ein meginástæða pess að staða kynjanna á vinnumarkaði er ójöfn (Angelov, Johansson \& Lindahl 2016; Kleven, Landais, Poxch, Steinhauer \& Zweimüller 2019), og ein ástæða pess hversu seint gengur að loka bilinu að jafnrétti kynja (Olivetti \& Petrongolo 2016; Blau \& Kahn 2017). Á síðari hluta 20. aldar var orðið nokkuð ljóst að ekki yrði mikið lengra komist ef ekki tækist að jafna fjölskylduábyrgð kynjanna. Á síðustu áratugum 20. aldar tóku norrænar pjóðir pví að stíga skref til að auka möguleika feðra til umönnunar eigin barna ekki síst með breytingum á löggjöf um fæðingarorlof. Svíar voru fyrstir til og veittu foreldrum sameiginlegan rétt til sex mánaða orlofs 1974 og opnuðu pannig glufu fyrir pátttöku feðra. Norðmenn stigu svo pað skref árið 1993 að binda hluta orlofsins, fjórar vikur, við feður og voru pví fyrstir til að veita feðrum sjálfstæðan og óframseljanlegan rétt til fæðingarorlofs (Brandth \& Kvande 2020). Svíar sigldu í kjölfarið 1995 (Duvander, Ferrarini \& Thalberg 2005), Danir 1998 (en afnámu 
pað 2002) (Rostgaard \& Lausten 2014), Íslendingar árið 2000 og Finnar 2013 (LammiTaskula 2017).

Íslenska löggjöfin frá árinu 2000 markar mikilvægt skref í stefnu stjórnvalda um að jafna fjölskylduábyrgð mæðra og feðra. Lögin póttu framsækin og vöktu mikla athygli á alpjóðavísu par sem lengi vel bauð ekkert annað land feðrum upp á jafnmarga óframseljanlega daga með sambærilegum greiðslum (Moss 2015). Par að auki áttu foreldrar sameiginlegan rétt til priggja mánaða. Markmið laganna var að tryggja barni samvistir við báða foreldra og gera bæði konum og körlum kleift að samræma fjölskyldu- og atvinnulíf. Lögin hafa nú verið í gildi i 20 ár og voru endurskoðuð árið 2020 og pví ástæða til að spyrja á pessum tímamótum hvort löggjöfin hafi verið árangursrík. Í greininni er byggt á skilgreiningu Luetjens, Mintrom og 't Hart (2019) á pví hvað teljist árangursrík opinber stefna (e. successful public policy). Til að stefna teljist árangursrík parf hún að valda æskilegum samfélagslegum breytingum, hafa pólitískt lögmæti og greina parf langtímastuðning og -áhrif. Í greininni er einkum horft til fyrstnefnda atriðisins, í skilgreiningu peirra Luetjens o.fl. (2019), pegar mat er lagt á árangur lagasetningarinnar. Megintilgangurinn er að greina breytingar á stöðu mæðra og feðra og leggja mat á hvort pær séu í samræmi við hið tvípætta markmið laganna. Annars vegar er spurt hvaða breytingar hafa orðið á pátttöku beggja foreldra í umönnun barna sinna frá pví lögin tóku gildi og hins vegar að hvaða marki hefur tekist að gera báðum foreldrum kleift að samræma vinnu og fjölskyldulíf.

Niðurstöður byggja á gögnum sem hefur verið aflað með endurteknum spurningakönnunum um hvernig foreldrar sem eignast sitt fyrsta barn hafa hagað atvinnupátttöku og umönnun barna sinna auk talnagagna frá Fæðingarorlofssjóði og niðurstöðum annarra rannsókna á áhrifum löggjafarinnar. Pær sýna að víðtæk sátt ríkti um lagasetninguna og að frá pví lögin tóku gildi hafa feður jafnt og pétt aukið pátttöku sína í umönnun barna, samhliða pví að dregið hefur úr mun á vinnutíma og vinnumarkaðspátttöku feðra og mæðra. Löggjöfin telst pví árangursrík í peim skilningi að hlutverk mæðra og feðra á atvinnumarkaði og heimafyrir hefur breyst og pokast nær markmiðum laganna um að tryggja barni samvistir við báða foreldra og gera foreldrum kleift að samræma fjölskyldu- og atvinnulíf. Баð er pó enn talsverður munur á milli feðra og mæðra. Vinnutími mæðra er styttri, pær taka lengra leyfi frá störfum í tengslum við fæðingu og axla stærri hluta umönnunar barna en feður gera.

\section{Einkenni árangursríkrar opinberrar stefnu}

Lög um fæðingar- og foreldraorlof frá árinu 2000 eru hluti opinberrar fjölskyldu- og jafnréttisstefnu. Stefnumótun er veigamikill páttur í starfsemi ráđuneyta, sveitarstjórna og opinberra stofnana og er tilgangur hennar að breyta ríkjandi ástandi. Pannig byggir opinber stefna á framtíðarsýn og hugmyndum um markmið sem æskilegt er að ná. Hún birtist meðal annars í samningum, sáttmálum, aðgerðaráætlunum og í lögum, en samkvæmt Héðni Unnsteinssyni og Pétri Berg Matthíassyni (2012) er löggjöf eitt áhrifamesta stefnumótunartækið. Lögum um fæðingar- og foreldraorlof (nr. 95/2000) er ætlað að hafa víðtæk áhrif, samanber hið tvípætta markmið laganna að jafna stöðu mæðra og 
feðra á vinnumarkaði og að tryggja barni samvistir við báða foreldra. Pegar lagt er mat á hvort um árangursríka stefnu hafi verið að ræða er ýmislegt sem vert er að hafa í huga. Almennt hefur fræðafólk lagt áherslu á að til pess að opinber stefna geti talist árangursrík purfi mismunandi hagsmunaaðilar að líta jákvæðum augum bæði á stefnumótunarferlið og pær breytingar sem stefnan hefur í för með sér (Hough o.fl. 2010). Pannig er um að ræða stefnumótun sem felur í sér samvinnu í stað miðstýrðrar ákvarðanatöku, eftirlits og stýringar (Osborne 2006).

Í skrifum sínum um opinbera stefnumótun fjalla Luetjens, Mintrom og 't Hart (2019) um hvenær stefna getur talist árangursrík. Pau byggja á hugmyndum McConnell (2010) sem tiltók prenns konar aðferðir við árangursmat. Í fyrsta lagi er hægt að meta ferilinn við stefnumótun (e. process assessment) í anda kerfiskenninga Easton (1953) og Lasswell (1956). Samkvæmt kenningunum er pað hlutverk stjórnvalda að skilgreina hvaða vandamál séu til staðar, ákvarða hvaða möguleikar eru í stöðunni, taka ákvarðanir og hrinda peim í framkvæmd. Mat á árangri í anda pessarar hugmyndafræði felst í pví að meta stefnuferlið. Í pessu felst að skoða hverjir koma að ákvarðanatöku við mótun stefnunnar og hvort hún öðlist hljómgrunn bæði meðal hagsmunaaðila og almennings.

Í öðru lagi er vert að meta hvaða ákvarðanir eru teknar og hvort ákvarðanirnar skili tilætluðum árangri (e. programmatic assessment). Par er áhersla lögð á að greina markmið stefnunnar, á hvaða hugmyndafræði hún byggir og hvaða leiðir eru valdar til að ná fram settum markmiðum, sem síðan liggur til grundvallar mati á pví hvort stefnan hafi mikilvæg áhrif. Undir pessa vídd falla svokallaðar útkomurannsóknir (e. outcome studies) par sem lagt er mat á hvort stefnan hafi orðið til pess að bæta hag pess hóps sem hún beindist að og hvort tilteknir hópar hagnist á stefnunni umfram aðra (McConnell 2010).

priðja víddin lýtur að pólitískum áhrifum stefnunnar (e. political assessment). Mótun opinberrar stefnu getur til dæmis orðið til pess að efla orðspor stjórnmálamanna og möguleika peirra á að ná endurkjöri eða styrkt grundvöll peirra stjórnarhátta sem stjórnvöld hafa að leiðarljósi. Pannig er unnt að meta hvort pólitísk sátt ríki um stefnuna og huga að pví hvort stefnumótunin auki hróđur peirra sem að henni koma.

Luetjens o.fl. (2019) bættu svo fjórðu víddinni við, um árangur yfir tíma (e. development over time). Pannig má meta árangur stefnu út frá pví hvort hún sé samfélagslega viðurkennd á öllum stigum ferlisins, allt frá mótun tillögu til áhrifa stefnunnar til langs tíma litið. Á pessum grunni setja Luetjens o.fl. (2019) fram eftirfarandi skilgreiningu á árangursríkri stefnumótun: Stefnumótun er árangursrík pegar a) hún sannanlega veldur samfélagslegum breytingum sem taldar eru æskilegar, b) ferli við mótun, ákvarðanatöku og afurðasköpun felur í sér að leitað sé lausna og tryggir stefnunni jafnframt pólitískt lögmæti og c) að pessu sé viðhaldið yfir langan tíma jafnvel pótt samfélagslegar breytingar eigi sér stað.

Oft skarast víddirnar fjórar og opinber stefna sem talin er valda æskilegum samfélagslegum breytingum (e. programmatic success) er gjarnan einnig metin árangursrík pegar stefnuferillinn eða pólitískur árangur stefnunnar eru til skoðunar (McConnell 
2010). Pannig er líklegra að stefnan feli í sér umbætur eða ábata pvert á hópa ef hún nýtur stuðnings almennings og hagsmunaaðila. Til dæmis er pað einkenni árangursríkrar opinberrar stefnu að innihald hennar og markmið er á almanna vitorði og umræður um mögulegar lausnir á málefninu, sem stefnan nær til, hefur gjarnan átt sér stað í pó nokkurn tíma. Pess vegna hlýtur árangursrík stefna oft mestan hljómgrunn pegar hún er fyrst sett fram, eða með orðum Luetjens o.fl. (2019, bls. 18), pá er pað einkenni árangursríkrar stefnu að stjórnvöld hafa náð að „hamra járnið á meðan pað er heitt“. Víðtækur stuðningur hagsmunaaðila og stuðningur pvert á pólitíska flokka til lengri tíma er jafnframt mikilvægur til pess að stefna teljist vera árangursrík. Dannig er t.d. mikilvægt að ekki verði stefnubreytingar við ríkisstjórnarskipti (Luetjens o.fl. 2019).

\section{Fyrri rannsóknir á árangri lagasetningar sem hvetur feđur til töku fæðingarorlofs}

Æ fleiri pjóðir hafa stigið skref í pá átt að hvetja feður til töku fæðingarorlofs með óframseljanlegum rétti. Meginástæður pessarar próunar er að fáir feður taka fæðingarorlof ef réttur foreldra er framseljanlegur og ef miklu munar á greiðslum í fæðingarorlofi og launatekjum (Koslowski, Blum, Dobrotić, Kaufman \& Moss 2021). Opinber stefna sem tryggir feðrum sjálfstæðan rétt til fæðingarorlofs, með tekjutengdum greiðslum, byggir á markmiði um að auka pátttöku feðra í umönnun barna sinna, enda sýna alpjóðlegar rannsóknir að virk pátttaka beggja foreldra í umönnun barns hefur mjög jákvæð áhrif á alhliða proska pess (sjá t.d. Cools, Fiva \& Kirkebøen 2015; Sarkadi, Kristiansson, Oberklaid \& Bremberg 2008). Auk pess er talið að aukið jafnræði í pví hvernig foreldrar skipta með sér orlofi styrki stöðu mæðra á vinnumarkaði, par sem löng fjarvera mæðra frá vinnumarkaði, vegna fæðingar barns, hefur neikvæð áhrif á laun peirra og framgangsmöguleika (Kahn, García-Manglano \& Bianchi 2014).

Sem fyrr segir eru ýmsar leiðir færar við mat á árangri opinberrar stefnu. Á alpjóðavísu hafa margar rannsóknir verið gerðar á pví hvaða samfélagslegu breytingar verða með tilkomu óframseljanlegs fæðingarorlofs fyrir feður og heyra pær pví undir pá vídd sem metur árangur út frá áhrifum lagasetningar eða lagabreytinga (e. programmatic assessment). Flestar pessara rannsókna fjalla um breytingar sem verða á umönnunarpátttöku og vinnutíma feðra en minna er vitað um hvaða breytingar verða á stöðu mæðra á vinnumarkaði við pað að feður öðlist sjálfstæðan rétt til töku fæðingarorlofs.

Fjölmargar rannsóknir sýna að umönnunarpátttaka feðra, eftir að fæðingarorlofi lýkur, eykst með tilkomu sjálfstæðs réttar feðra til töku fæðingarorlofs (sjá t.d. Cools, Fiva \& Kirkebøen 2015; Kotsadam \& Finseraas 2011; Rege \& Solli 2013; Schober 2014). Pá kom fram í nýlegri skýrslu Alpjóðaheilbrigðismálastofnunar (Incley o.fl. 2020) að drengir og stúlkur á Íslandi mátu samskipti sín við feður jákvæðari en börn frá öllum samanburðarlöndunum, 41 talsins. Rannsóknin náði til fyrstu íslensku árganganna sem nutu góðs af auknum rétti feðra til töku fæðingarorlofs og hafa rannsakendur leitt að pví líkur að pessi árangur sé afleiðing af auknum möguleikum feðra til að annast um börn sín í kjölfar pess að peir öðluðust sjálfstæðan rétt til töku orlofs (Ársæll Arnarsson 
\& Hermína Gunnpórsdóttir 2016). Nýlegar samanburðarrannsóknir á samskiptum foreldra og barna á Norðurlöndunum benda einnig til pess að tengsl séu á milli lengdar fæðingarorlofs feðra og gæða tengslamyndunar peirra við börn sín (Arnarsson, Potrebny, Torsheim \& Eriksson 2019).

рó að fæðingarorlofslöggjöf í nágrannalöndum okkar hafi pað ekki að markmiði að draga úr skilnaðartíðni, eru vísbendingar um að fæðingarorlofsnýting feðra hafi óbein áhrif vegna aukinnar pátttöku peirra í umönnun og heimilishaldi. Í pví sambandi má benda á að Kotsadam og Finseraas (2011) komust að pví að tilkoma sjálfstæðs réttar feðra til fæðingarorlofs í Noregi varð til pess að draga úr ágreiningi foreldra um hvernig beri að skipta heimilisverkum. Sömuleiðis leiddi rannsókn Evertsson, Boye og Erman (2018) í ljós að pví lengra fæðingarorlof sem sænskir feður nýttu, pví ánægðari voru mæðurnar með pað hvernig verkaskiptingu við umönnun barna peirra var háttað. Pannig virðist fæðingarorlof feðra auka líkur á samvinnu og samstöðu foreldra, sem hefur jákvæð áhrif á stöðugleika sambandsins. Nýleg norræn rannsókn sýndi að minna er um skilnaði hjá pörum par sem faðirinn hefur tekið fæðingarorlof heldur en par sem pað hefur ekki verið gert (Lappegård o.fl. 2020). Pá sýndi íslensk rannsókn að með tilkomu sjálfstæðs réttar feðra til fæðingarorlofs dró úr líkum á skilnaði (Olafsson \& Steingrimsdottir 2020).

Rannsóknir sýna einnig að í löndum par sem réttur feðra til töku fæðingarorlofs er óframseljanlegur, vinna feður almennt færri vinnustundir (Bünning \& Pollmann-Schult 2016), enda hefur verið sýnt fram á að pví lengra fæðingarorlof sem feður nýta, peim mun minna vinna peir utan heimilisins eftir pví sem barn peirra verður eldra (sjá t.d. Duvander \& Jans 2009; Kitterød 2013; Schober 2014). Niðurstöður nýlegrar rannsóknar sem bar saman fæðingarorlofsnýtingu, vinnutíma og umönnun barna á Íslandi og Spáni sýndu samskonar tengsl, en í báðum löndum dró úr vinnutíma feðra með aukinni nýtingu peirra á orlofi. Rannsóknin sýndi enn fremur að fæðingarorlofsnýting feðra hefur óbein áhrif á pátttöku peirra í umönnun barna sinna eftir að orlofi lýkur, í gegnum styttri vinnutíma (Arnalds, Belope-Nguema, Eydal \& Fernández-Cornejo 2021).

Tengslin milli pess hvernig foreldrar haga fæðingarorlofi og atvinnupátttöku mæðra hafa minna verið rannsökuð en pó sýna rannsóknarniðurstöður að í löndum sem bjóða upp á langt fæðingarorlof fyrir mæður er bilið milli atvinnupátttöku mæðra og barnlausra kvenna stærra en í löndum par sem mæður taka styttra fæðingarorlof (Nieuwenhuis, Need \& Van der Kolk 2017). Dannig getur of löng fjarvera kvenna frá vinnumarkaði vegna umönnunar ungra barna gert peim erfitt að hefja vinnu utan heimilis síðar meir. Dýskaland er dæmi um land sem hefur einkennst af lítilli vinnumarkaðspátttöku mæðra, en eftir að ný fæðingarorlofslög tóku gildi árið 2007, sem fólu í sér tekjutengdar greiðslur og möguleika á lengra fæðingarorlofi ef feður nýttu einhvern hluta orlofstímans, jókst atvinnupátttaka mæðra að loknu fæðingarorlofi (Kluve \& Tamm 2013).

Ísland hefur töluverða sérstöðu umfram önnur lönd sem bjóða upp á sjálfstæðan rétt feðra til töku fæðingarorlofs. Degar mat er lagt á árangur slíkrar stefnu er mikilvægt að hafa í huga að lengi vel var óframseljanlegur réttur feðra, par sem greiðslur eru hátt hlutfall tekna, lengstur á Íslandi (Moss 2015). Enn fremur hefur atvinnupátttaka karla og 
kvenna löngum verið há á Íslandi samanborið við önnur Evrópulönd. Af peim sökum er mikilvægt að rýna betur pær samfélagslegu breytingar sem hafa orðið á stöðu mæðra og feðra eftir að lög um fæðingar- og foreldraorlof (nr. 95/2000) tóku gildi.

\section{Bakgrunnur rannsóknar: Fæđingarorlof á Íslandi}

Hérlendis hefur löggjafinn um áratuga skeið lagt áherslu á að börn eigi rétt á umönnun beggja foreldra, sbr. barnalög (nr. 76/2003), pingsályktun um mótun opinberrar fjölskyldustefnu (nr. 1230/1996-1997) og Sáttmála um réttindi barns (Lög um samning Sameinuðu pjóðanna um réttindi barnsins nr. 19/2013). Fæðingarorlofslöggjöfin frá 2000 var pví hluti af opinberri stefnumótun sem ætlað er að tryggja rétt barna til umönnunar beggja foreldra samhliða pví markmiði að gera mæðrum og feðrum kleift að sampætta vinnu og fjölskyldulíf.

\subsection{Aðdragandi lagasetningarinnar 2000}

Umræða um jafnrétti kynja á Íslandi var töluverð á tíunda áratug 20. aldar og beindist meðal annars að ójafnri pátttöku á vinnumarkaði. Rannsóknir sýndu að barneignir höfðu mjög mismunandi áhrif á stöðu kynjanna á vinnumarkaði. Eftir að hafa eignast barn juku feður launavinnu sína til að ná endum saman en mæður drógu úr launaðri vinnu til að geta betur sinnt fjölskyldunni (Hagstofa Íslands 2001; Gallup 2006). Nefnd á vegum forsætisráðuneytisins komst að peirri niðurstöðu að 7,5\% til 11\% launamunar kynja á Íslandi mætti rekja til pess að hjónaband og barneignir hefðu önnur áhrif á laun karla en kvenna (Nefnd um efnahagsleg völd kvenna 2004).

Barna- og fjölskyldumál voru töluvert rædd á Íslandi við lok síðustu aldar og pá meðal annars fæðingarorlof og hversu miklu lakara pað væri á allan hátt en hjá öðrum norrænum pjóðum. Gagnrýnin fólst í pví að hið sex mánaða langa orlof, skv. lögum frá 1981, væri of stutt, að greiðslur sem foreldrar á almennum vinnumarkaði fengju í fæðingarorlofi væru undir lágmarkslaunum og að kerfið biði ekki upp á neinn sveigjanleika par sem t.d. væri enginn möguleiki að vera í hlutaorlofi. Sömuleiðis var bent á að pó formlega væri mögulegt fyrir foreldra að skipta með sér orlofinu pá væru í raun aðeins mæður sem nýttu pað. Баð væri töluverð hindrun í vegi jafnréttis kynja, græfi undan konum á vinnumarkaði og svipti karla möguleikum til að mynda náin tengsl við börn sín. Loks var bent á að engin skynsamleg rök væru fyrir pví að réttur til orlofs væri mismunandi á peim grunni hvort mæður störfuðu á opinbera vinnumarkaðnum eða hinum almenna (Eydal \& Gíslason 2008).

Á Alpingi voru flutt frumvörp til breytinga og utan pings beittu kvennahreyfingar og stéttarfélög sér fyrir breytingum. Skref voru stigin í átt til breytinga hjá einstaka sveitarfélögum (sjá nánar um aðdragandann í Eydal \& Gíslason 2008; Ingólfur V. Gíslason 2007) og í desember 1997 sampykkti Alpingi breytingar á lögum um fæðingarorlof sem fólu í sér tveggja vikna fæðingarorlof fyrir feður. Réttinn purfti að nýta á fyrstu átta vikum í lífi barnsins og greiðslur fóru eftir pví hvort faðir starfaði á almenna eða opinbera vinnumarkaðnum, par sem peir sem voru á opinbera markaðnum héldu launum sínum en peir sem störfuðu á almenna markaðnum fengu bætur Tryggingastofnunar 
ríkisins (Lög um breytingu lagaákvæða um fæðingarorlof nr. 147/1997). Frekari skref voru stigin í átt til breytinga, svo sem pegar VR hafði árið 1999 frumkvæði að pví að bjóða félagsmönnum 80\% launa í fæðingarorlofi. •ar með var komið fordæmi fyrir pví að bjóða feðrum á almennum markaði tekjutengdar greiðslur („,VR skoðar að greiða full laun í fæðingarorlofi“" 2000).

Samsteypustjórn Framsóknar- og Sjálfstæðisflokks endurnýjaði samstarf sitt að loknum kosningum og í stefnuyfirlýsingu stjórnarinnar sagði meðal annars: „Jöfn tækifæri karla og kvenna verði tryggð í hvívetna svo sem með lengingu fæðingarorlofs og jöfnun réttar mæðra og feðra til töku pess“ (Stefnuyfirlýsing ríkisstjórnarinnar 1999). Pessu var hrint í framkvæmd í maí 2000 pegar Páll Pétursson, páverandi félagsmálaráðherra, mælti fyrir stjórnarfrumvarpi um fæðingar- og foreldraorlof. Engar breytingar voru gerðar á frumvarpinu í meðförum pingsins og á endanum var bað sampykkt mótatkvæðalaust, einn pingmaður sat hjá (Eydal \& Gíslason 2008).

\subsection{Lög um fæðingar- og foreldraorlof}

Lögin frá 2000 fólu í sér ýmsar mikilvægar breytingar frá fyrri löggjöf. Orlofið var lengt úr sex í níu mánuði, prír mánuðir voru bundnir föður, prír móður og premur gátu foreldrar skipt að vild. Peir prír mánuðir sem við bættust voru peir sem merktir voru feðrum og sá fyrsti kom til framkvæmda árið 2001, annar 2002 og sá priðji 2003. Í löggjöfinni fólst aukinn sveigjanleiki par sem töku fæðingarorlofs mátti dreifa á 18 mánuði. Enn fremur gátu foreldrar verið saman í orlofi allan tímann eða hluta hans, unnt var að vera í hlutavinnu og hlutaorlofi og pað var ekki fyrr en barnið er orðið 18 mánaða sem ónýttur réttur féll niður. Greiðslur í fæðingarorlofi urðu tekjutengdar pannig að foreldrar á vinnumarkaði fengu greiðslur sem námu 80\% af meðallaunum. Ákveðið gólf var á greiðslum (p.e. ef 80\% fór undir ákveðið mark voru greiðslur hækkaðar) en ekkert pak. Foreldrar sem voru utan vinnumarkaðar eða í minna en 25\% starfi fengu fæðingarstyrk. Sérstakur fæðingarorlofssjóður var stofnaður, til að annast greiðslur, og fær tekjur sínar með ákveðnum hluta tryggingagjalds atvinnurekenda. Auk fæðingarorlofs öðluðust foreldrar, hvort um sig, rétt til priggja mánaða ólaunaðs foreldraorlofs sem unnt var að nýta par til barnið hefur náð átta ára aldri (Lög um fæðingar- og foreldraorlof nr. 95/2000).

Mesta athygli vakti vissulega prískipting orlofsins sem víða erlendis hefur síðan verið kallað „íslenska módelið.“ Tilgangurinn var ekki hvað síst jafnréttistengdur p.e. að auka möguleika feðra til að annast um börn sín og jafna pannig tækifæri feðra og mæðra til að sampætta fjölskyldulíf og pátttöku á vinnumarkaði. Önnur skref hafa einnig verið stigin í sömu átt, svo sem lög um sameiginlega forsjá barna við skilnað árið 1992 og próunin í átt til skiptrar búsetu barna eftir skilnað (Sigrún Júlíusdóttir \& Sólveig Sigurðardóttir 2013).

Ekki urðu miklar umræður í samfélaginu um lagafrumvarpið enda lítill tími frá pví frumvarpið var lagt fram og par til pað var sampykkt. Margir fögnuðu en peir fáu sem gagnrýndu bentu fyrst og fremst á tvo pætti sem væru neikvæðir. Annars vegar kostnað (sjá t.d. Sigríður Andersen \& Soffía Kristín Pórðardóttir 2000) og hins vegar stöðu barna einstæðra foreldra (sjá t.d. Albert Snorrason \& Halldóra Einarsdóttir 2000). Félagsmála- 
ráðherra vék að peim pætti í framsöguræðu sinni er hann sagði: „, konar tilfellum eða reyndar prenns konar sem barn á ekki kost á níu mánaða sólarhringssamvistum við foreldri. Фað er í fyrsta lagi ef móðir kýs að feðra ekki barn sitt, í öðru lagi ef forsjárforeldri neitar pví foreldri sem er án forsjár um fæðingarorlof og eins kann svo að fara ef annað foreldri er erlendis“ (Pingfundur nr. 104/2000). Nokkrir pingmenn viðruðu áhyggjur sínar af pessu atriði við umræðurnar og eins og nánar er fjallað um síðar í greininni voru möguleikar á tilfærslu réttinda auknir pann tíma sem lögin voru í gildi (og enn frekar við heildarendurskoðun laganna 2020). Skoðanakannanir sýna að löggjöfin naut almenns fylgis, bæði meðal almennings og atvinnurekenda (Bryndís Jónsdóttir 2007; Gallup 2003).

Vafalítið var fjármögnun kerfisins ein af ástæðunum fyrir pví að lögin mættu svo lítilli andstöðu. Atvinnurekendur greiddu nú pegar tryggingagjald og hluti pess rann í atvinnuleysistryggingasjóð. Atvinnuleysi hafði í nokkur ár verið hverfandi á Íslandi og lausnin á fjármögnun varð að hluti tryggingagjalds rann nú í Fæðingarorlofssjóð og hlutinn sem rann í atvinnuleysistryggingasjóð lækkaði samsvarandi (Eydal \& Gíslason 2008). Hér var pví aðeins um að ræða tilfærslu á fjármagni og hafði engin áhrif gagnvart launagreiðendum. Önnur ástæða pess að lögin mættu lítilli andstöðu var að enginn var verr settur eftir en áður. Hér var ekki söguleg hefð fyrir löngu fæðingarorlofi meðal mæðra og mánuðir feðranna voru hrein viðbót við pá sex mánuði sem orlofið hafði verið frá 1991. Í öðrum löndum, par sem hefð hefur verið fyrir löngu orlofi sem mæður hafa einkum notað, pá hefur sjálfsstæðum rétti verið komið á með pví að færa slíka mánuði til feðra og pað hefur oft mætt andstöðu (Einarsdóttir \& Pétursdóttir 2009; Eydal \& Gíslason 2008).

\subsection{Breytingar á lögum og tilkoma nýrra laga}

Lögunum var breytt nokkrum sinnum á pessum 20 árum. Fernt er par mikilvægast. Í fyrsta lagi pað sem snýr að greiðslum í orlofi. Líkt og áður kom fram var upphaflega ekkert pak á greiðslum, foreldrar sem verið höfðu á vinnumarkaði fengu 80\% launa meðan á orlofi stóð. Árið 2004 var pak sett á greiðslur en pakið var pað hátt að ekki ráku sig í pað nema 2,3\% feðra og 0,3\% mæðra fyrsta árið (Fæðingarorlofssjóður e.d.). Í kjölfar bankahrunsins haustið 2008 var víða skorið niður í velferðarkerfinu og fæðingarorlofið ekki undanskilið. Рakið var lækkað í prígang 2008 og 2009, og fór úr pví að vera 480.000 kr. í 300.000 kr. á einu ári. Auk pess varð breyting árið 2009 sem fól í sér að foreldrar með yfir 200.000 kr. í mánaðarlaun fengu 75\% af launum umfram pá upphæð. Degar pakið var hvað lægst hafði pað áhrif á greiðslur til 43\% feðra og 18\% mæðra (Eydal \& Gíslason 2014). Баð var hins vegar alltaf ljóst af orðum stjórnmálamanna að petta væru bráðabirgðaráðstafanir og pakið yrði hækkað aftur um leið og staða ríkisfjármála leyfði. Leiðrétting hófst árið 2013 og hefur síðan verið framkvæmd í áföngum pannig að árið 2017 (síðasta ár sem lokatölur liggja fyrir um) hafði pakið áhrif á greiðslur til 29,3\% feðra og 11,5\% mæðra (Fæðingarorlofssjóður e.d.).

Önnur breyting fól í sér að orðalag var gert kynhlutlaust og par með reynt að stuðla að pví að sem fjölbreyttastar fjölskyldur ættu kost á fæðingarorlofi. Með lögum nr. 
65/2006 um réttarstöðu samkynhneigðra var „,faðir og móðir“" breytt 1 „báðir foreldrar“ og „,kona“ breyttist í „,móðir.“ Dessu var svo fylgt eftir með lögum um breytingu á lögum um fæðingar- og foreldraorlof nr. 74/2008 par sem „móðir“ verður „foreldri.“ Lokahnykkurinn var svo breyting með lögum nr. 153/2020 vegna laga um kynrænt sjálfræði, pegar „bæði konum og körlum“ varð „foreldrum.““

Driðja meginbreytingin sneri að óframseljanlega réttinum. Í upphaflegu lögunum var aðeins ein undantekning frá peirri reglu að peir prír mánuðir sem bundnir eru öðru foreldri væru óframseljanlegir. Dessi undantekning var ef annað foreldri andast áður en pað hafði fullnýtt rétt sinn. Pá færðist pað sem eftir var á hitt foreldrið. Með breytingu á lögum um fæðingar- og foreldraorlof nr. 74/2008 var pessi réttur rýmkaður. Ef foreldri andast á meðgöngu og barnið fæðist lifandi hefur eftirlifandi foreldri rétt á níu mánuðum. Dá var leitt ílög að ef foreldri er ófært um að annast barnið á fyrstu 18 mánuðum, vegna sjúkdóms, afleiðingar slyss eða afplánunar refsivistar, má pað framselja sinn rétt til hins foreldrisins. Með lögum nr. 143/2012 fengu einhleypar konur, sem fengið höfðu tæknifrjóvgun, og einhleypir sem ættleiða, rétt til níu mánaða orlofs.

Í fjórða lagi er svo lenging orlofsins. Umræður um pað atriði hófust fljótlega eftir lagasetninguna 2000 og raunar nefndu nokkrir pingmenn við umræður um lagafrumvarpið að pörf væri á að lengja orlofið enn frekar en par væri lagt til. Í málefnayfirlýsingu samstjórnar Samfylkingar og Sjálfstæðisflokks, sem tók við völdum 2007, var ákvæði um að fæðingarorlof yrði lengt 1 áföngum án pess að nefnt væri hversu langt pað yrði eða hvernig ætti að skipta pví milli foreldra (Stefnuyfirlýsing ríkisstjórnar 2007). En áður en ríkisstjórnin setti málið á dagskrá hrundi íslenska bankakerfið og við tók niðurskurðartímabil. Málið var aftur til umræðu nokkrum árum síðar og í desember 2012 sampykkti Alpingi lengingu orlofsins í 12 mánuði og skyldi skiptingin vera fimm mánuðir fyrir hvort foreldri og tveir mánuðir til skiptanna (Lög nr. 143/2012). Pessi lenging var afturkölluð með lögum nr. 140/2013 um ýmsar forsendur frumvarps til fjárlaga fyrir árið 2014.

Í október 2017 var mynduð ríkisstjórn Framsóknarflokks, Sjálfstæðisflokks og Vinstrihreyfingarinnar - græns framboðs. Í stjórnarsáttmála sagði meðal annars: „Meðal pess sem sett verður á dagskrá í samtali stjórnvalda og aðila vinnumarkaðarins er lenging fæðingarorlofs og hækkun orlofsgreiðslna í fæðingarorlofi““ (Stefnuyfirlýsing ríkisstjórnar 2017). Í desember 2019 lagði ríkisstjórnin svo fram frumvarp um málið par sem lagt var til að orlofið yrði lengt 112 mánuði. Nokkur umræða varð um málið á pingi og var niðurstaðan að orlofið var lengt í 10 mánuði árið 2020 og ákveðið að skiptingin skyldi vera 4-4-2. En lögin frá 2019 kváðu einnig á um að árið 2021 eigi orlofið að verða 12 mánuðir og skiptast að lágmarki 4-4-2 en ráðherra var falið að leggja til skiptingu á næsta pingi (Lög um breytingu á lögum um fæðingar- og foreldraorlof, nr. 95/2000, með síðari breytingum (lenging fæðingarorlofs) nr. 149/2019). Ráðherra skipaði samstarfshóp til að fara í saumana á málinu og hópurinn lagði til að skiptingin yrði sex mánuðir fyrir hvort foreldri en að foreldrar gætu framselt fjórar vikur til hins foreldrisins. Eftir talsverðar umræður á Alpingi, lagði velferðarnefnd til að orlofið yrði sex mánuðir fyrir hvort foreldri en að foreldrar geti framselt sex vikur til hins foreldrisins og var pað sam- 
pykkt (Lög nr. 144/2020). Markmiðssetning laganna er eins og peirra sem sampykkt voru vorið 2000.

\subsection{Nýting á fæđingarorlofi}

Tölur frá Fæðingarorlofssjóði sýna að feður hafa almennt nýtt rétt sinn til töku fæðingarorlofs. Mynd 1 sýnir nýtingu feðra á rétti sínum, annars vegar hlutfall peirra sem eitthvað nýta og hins vegar pann dagafjölda sem peir nota að meðaltali.

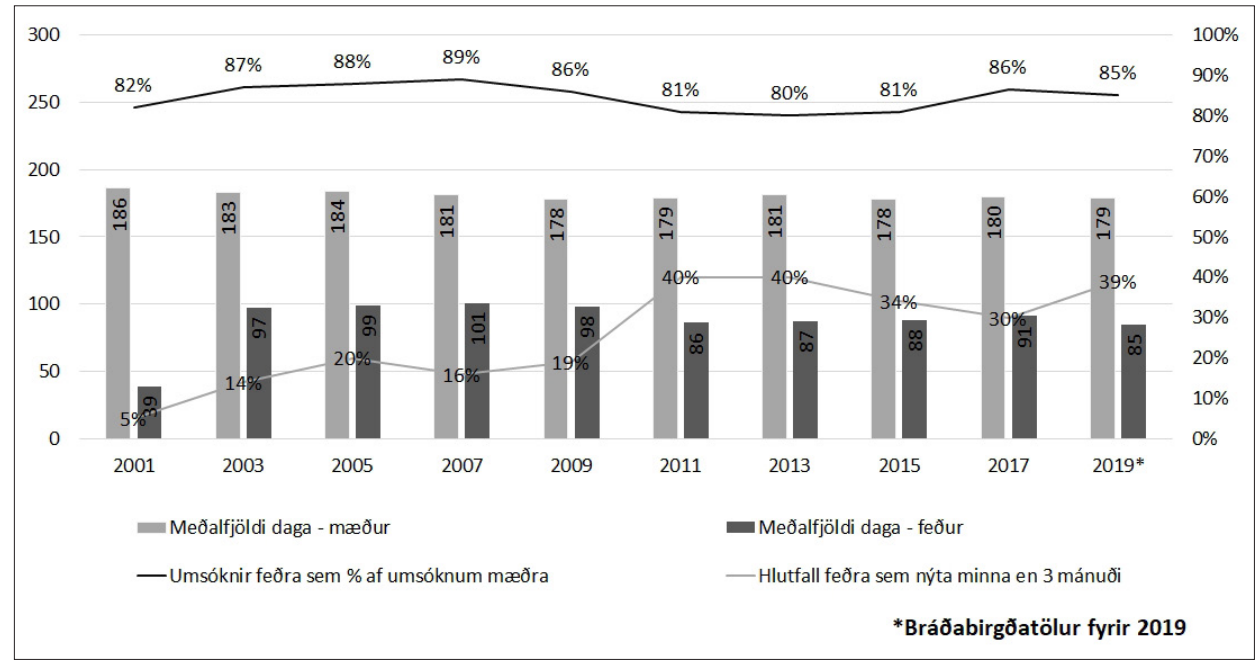

Mynd 1. Fæðingarorlofsnýting feđra og mæðra 2001 til 2019

Heimild: Fæðingarorlofssjóður e.d.

Eins og pegar hefur komið fram, var orlofið lengt í áföngum pannig að feður fengu einn mánuð 2001, annan 2002 og frá og með 2003 var priggja mánaða sjálfstæður réttur feðra að fullu kominn til framkvæmda. Strax árið 2001 nýttu 82,4\% feðra sér réttinn og tóku að meðaltali 39 daga. Árið 2002 var hlutfallið 83,6\% og meðaltals dagafjöldi 68 og pegar lögin voru að fullu komin til framkvæmda var hlutfallið 86,6\% og dagafjöldinn 97 . Flest ár síðan hefur hlutfallið verið svipað, sem og dagafjöldinn, ef undan eru skilin árin eftir efnahagshrun pegar greiðsluskerðingar voru sem mestar. Milli 13,3\% og 23\% feðra hafa nýtt eitthvað af sameiginlega réttinum. Mæður hafa á hinn bóginn undantekningarlítið fullnýtt sína prjá mánuði og hafa pær nýtt að meðaltali 180 daga (Fæðingarorlofssjóður e.d.). Pessi skipting er í fullu samræmi við pað sem alpjóðlegar samanburðarrannsóknir hafa sýnt, sameiginlegur réttur er alla jafna nýttur af mæðrum (Duvander \& Lammi-Taskula 2011; Moss, Duvander \& Koslowski 2019).

Sáralítið er vitað um einkenni peirra fjölskyldna par sem feður nota eitthvað af sameiginlega réttinum. Ein eigindleg rannsókn var gerð meðal feðra sem nýta sameiginlega réttinn og í peim tilvikum var pað fyrst og fremst vinnumarkaðsstaða móður sem var megin skýringarpáttur fyrir pví að feður nýttu sameiginlega réttinn (Ingólfur V. Gíslason 
2005). Heldur meira er vitað um pau 10 til 15\% feðra sem ekki taka neitt orlof og hvaða pættir pað eru sem tengjast orlofslengd feðra. Í fyrsta lagi tekur hærra hlutfall feðra í sambúð orlof borið saman við hlutfall feðra sem búa ekki með barnsmóður. Samkvæmt rannsókn meðal foreldra sem áttu sitt fyrsta barn árið 2009, nýttu 76\% feðra (74 einstaklingar) sem aldrei höfðu búið með móðurinni, ekkert orlof (Lárusdóttir, Eydal \& Arnalds væntanleg). Í rannsókn meðal foreldra barna sem voru fædd 2009 jukust líkur á töku feðra ef báðir foreldrar voru í fullri vinnu og að sama skapi var líklegra að feður tækju ekkert orlof ef hvorugt foreldranna varí fullri vinnu (Arnalds, Duvander, Eydal \& Gíslason 2019). Fyrst eftir lagasetninguna árið 2000 var nýtingin mest meðal tekjuhæstu feðranna (p.e. feðra með tekjur í hæsta fjórðungi). Бað dró úr nýtingu peirra eftir að paki var komið á greiðslur árið 2004 og á árunum fyrir hrun var lítill munur á meðalfjölda daga sem nýttir voru af feðrum í öðrum, priðja og hæsta tekjufjórðungi. Á hinn bóginn nýttu feður í lægsta fjórðungnum fæsta daga, að meðaltali. Petta mynstur breyttist pegar pak á greiðslur var lækkað verulega eftir bankahrun. Pá dró úr nýtingu allra tekjuhópa en fallið var mest meðal tekjuhæstu feðranna og árið 2012 var nýtingin minnst í peim hópi (Sigurðardóttir \& Garðarsdóttir 2018). Óbirtar tölur Fæðingarorlofssjóðs sýna að eftir að pak á greiðslur tók að hækka, jókst almennt nýting feðra á fæðingarorlofi, en pó ekki meðal feðra í lægsta og hæsta tekjuhópnum (Fæðingarorlofssjóður e.d.).

Tölulegar upplýsingar frá Fæðingarorlofssjóði gefa vísbendingar um aukinn hlut feðra í umönnun barna sinna en auk fæðingarorlofsnýtingar er mikilvægt að horfa til pess hvernig foreldrar skipta með sér umönnun og haga atvinnupátttöku eftir að fæðingarorlofi lýkur. Verður nú vikið að rannsókn höfunda á pessum páttum.

\section{Aðferðir og gögn}

Höfundar hafa gert fjórar kannanir meðal foreldra um atvinnupátttöku og umönnun fyrstu prjú árin eftir að peir eignast sitt fyrsta barn, í peim tilgangi að leggja mat á árangur lagasetningarinnar. Gagna var fyrst aflað árið 2001, meðal foreldra sem eignuðust sitt fyrsta barn árið 1997, p.e. fyrir gildistöku laganna. Næsta könnun náði til foreldra sem eignuðust sitt fyrsta barn árið 2003, eftir að lögin höfðu komið að fullu til framkvæmda. priðja könnunin náði til foreldra sem eignuðust sitt fyrsta barn árið 2009, eftir efnahagshrunið og loks var gerð könnun árið 2018 meðal foreldra sem eignuðust sitt fyrsta barn árið 2014.

Tafla 1. Framkvæmd og heimtur

\begin{tabular}{lcccc}
\hline & \multicolumn{4}{c}{ Gagnaöflunartímabil } \\
\cline { 2 - 4 } & 2001 & $2007-2008$ & 2014 & 2018 \\
\cline { 2 - 4 } Aðferð við gagnaöflun & Póstkönnun & Póst- og netkönnun & Netkönnun & Netkönnun \\
Foreldrar barna fædd & 1997 & 2003 & 2009 & 2014 \\
Fjöldi svarenda & 890 & 874 & 1218 & 944 \\
Svarhlutfall & $57 \%$ & $56 \%$ & $63 \%$ & $57 \%$ \\
Móđir skráir svör & Ekki vitað & $99 \%$ & $75 \%$ & $72 \%$ \\
\hline
\end{tabular}


Framkvæmd var með peim hætti að póstkönnun, eða kynningarbréf sem innihélt slóð að netkönnun, var sent á lögheimili barns. Í könnuninni voru foreldrar beðnir um að skrá hvernig atvinnupátttöku var háttað mánuð fyrir mánuð ári fyrir fæðingu og par til barnið er orðið priggja ára. Einnig var spurt hvernig foreldrar skiptu með sér umönnun barnsins fyrstu prjú æviárin og hvernig foreldrum gekk að samræma fjölskyldu- og atvinnulíf. Foreldrar höfðu val um hvort peirra svaraði könnuninni eða hvort peir svöruðu könnuninni í sameiningu en í flestum tilfellum var pað móðirin sem skráði, pó dregið hafi úr pví með árunum að móðir svari ein síns liðs (sjá töflu 1). Gögnin, sem aflað var með fjórðu könnuninni, voru auðguð með gögnum frá Fæðingarorlofssjóði um orlofsnýtingu foreldra.

Greiningin felur í sér mat á samfélagslegum áhrifum löggjafarinnar (e. programmatic assessment). Gögnin voru greind með lýsandi tölfræði sem sýnir breytingar á hlutfallslegri dreifingu svara við spurningum um umönnun og atvinnupátttöku mæðra og feðra frá pví lögin tóku gildi.

\section{5. Árangur lagasetningarinnar}

Sem fyrr segir var lögunum frá 2000 ætlað að stuðla að tvennu, tryggja barni samvistir við báða foreldra og gera foreldrum kleift að samræma atvinnu- og fjölskyldulíf. Niðurstöður kannananna gefa mynd af pví hvernig til hefur tekist að ná pessu tvípætta markmiði.

\subsection{Samvistir barna við báđa foreldra}

Mynd 2 sýnir hvernig foreldrar skiptu með sér umönnun barnsins fyrstu prjú æviárin. Myndin sýnir að hlutfall foreldra sem skiptu umönnun barnsins jafnt á milli sín hækkaði mikið eftir að lögin tóku gildi og hvernig hlutur feðra jókst jafnt og pétt allt rannsóknartímabilið.

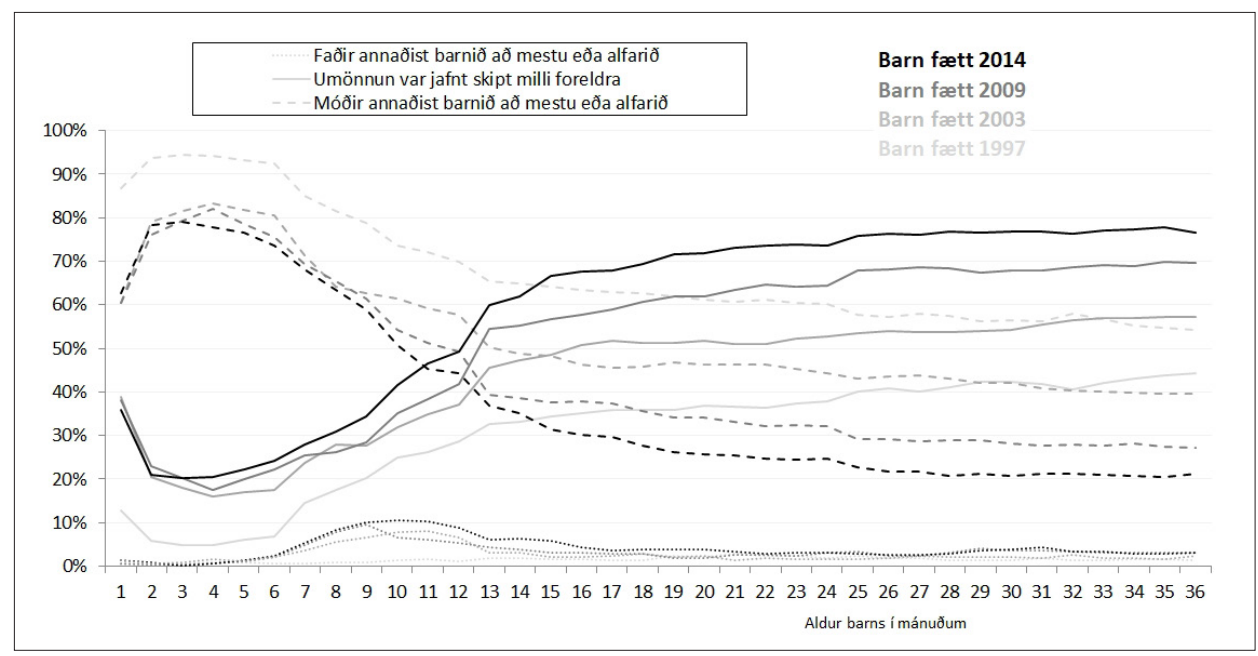

Mynd 2. Skipting umönnunar að degi til meðal foreldra sem áttu sitt fyrsta barn 1997, 2003, 2009 og 2014 - Foreldrar í sambúð/hjónabandi sem ekki eignuðust annađ barn á rannsóknartímabilinu 
Í fyrstu könnuninni meðal foreldra barna fædd árið 1997, áður en lögin tóku gildi, var hlutfall foreldra í sambúð eða hjónabandi sem skiptu umönnun jafnt sín á milli hæst 40\% við priggja ára aldur barns, en í meirihluta fjölskyldna var pað móðirin sem sá alfarið eða аð mestu leyti um umönnun barns. Sams konar mæling meðal foreldra sem eignuðust sitt fyrsta barn 2003, pegar lögin höfðu að fullu komið til framkvæmda, sýndi að hlutfall foreldra, sem skipti umönnun barns jafnt sín á milli, jókst til muna. Nýrri mælingar sýna áframhaldandi próun í sömu átt, en aukningin er pó fyrst og fremst eftir fyrsta æviár barnsins. Við priggja ára aldur barna sem fæddust 2014 sögðu rétt tæplega 80\% foreldra pátttöku peirra jafna í umönnun barna sinna. Рað má einnig sjá að jafnræði í umönnun á sér stað fyrr og fyrr í lífi barna. Hlutfall barna fædd 1997 sem nutu umönnunar beggja foreldra varð aldrei hærra en hlutfall peirra sem mæður önnuðust að mestu um. Eftir að lögin tóku gildi breyttist petta og við 14 mánaða aldur barna sem voru fædd 2003 var hlutfall barna sem báðir foreldrar önnuðust um hærra en peirra sem voru að mestu í umönnun mæðra. Hjá börnum fæddum 2009 gerist petta við 12 mánaða aldur og fyrir börn sem fæddust 2014 var breytingin pegar barnið var 10 mánaða gamalt.

Samskonar próun má sjá meðal foreldra sem ekki deila lögheimili (sjá mynd 3). Í fyrstu könnuninni sögðu einungis um 5\% mæðra, sem ekki bjuggu með barnsföður, að umönnun barnsins væri jafnt skipt milli foreldra. Hlutfallið var svipað í næstu könnun en hækkaði síðan verulega. Í könnuninni sem náði til foreldra barna fædd 2014 kvaðst ríflega fjórðungur foreldra, sem ekki deildu lögheimili, skipta umönnun jafnt sín á milli. Hér gætir einnig vafalítið áhrifa pess að sameiginleg forsjá var gerð að meginreglu við skilnað eða sambúðarslit árið 2006 (Lög um breytingu á nokkrum lögum á sviði sifjaréttar nr. 69/2006).

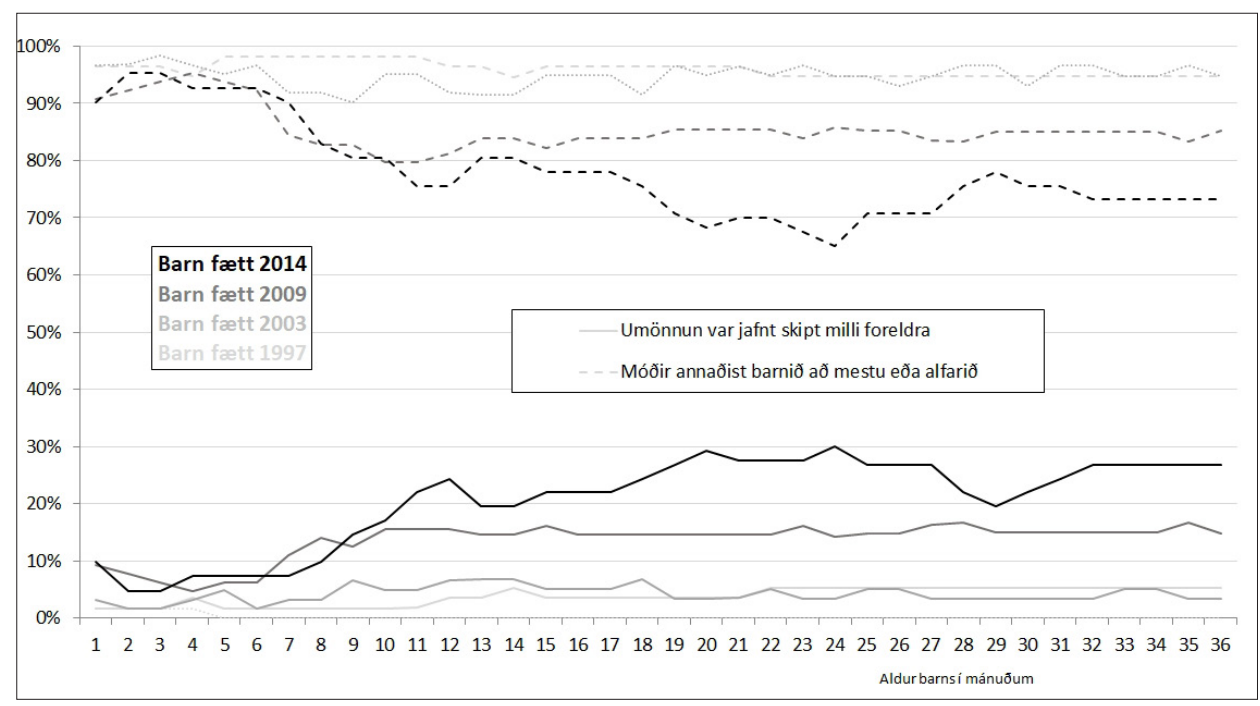

Mynd 3. Skipting umönnunar að degi til međal foreldra sem áttu sitt fyrsta barn 1997, 2003, 2009 og 2014 - Foreldrar sem bjuggu ekki saman við fæðingu barns 
Niðurstöður sýna að prátt fyrir að hlutdeild feðra, sem ekki deila lögheimili með börnum sínum, hafi aukist jafnt og pétt pá njóta börn sem ekki búa með báðum foreldrum í minna mæli umönnunar beggja foreldra en börn sem deila heimili með báðum foreldrum. Ítrekað hefur verið bent á mikilvægi pess að bregðast við pví með auknum stuðningi og ráðgjöf við foreldra sem ekki búa saman á meðgöngu (sjá t.d. Dingskjal nr. 1502/2017-2021).

Sem fyrr segir, voru svör foreldra við fjórðu könnuninni tengd við gögn Fæðingarorlofssjóðs um orlofsnýtingu foreldra. Gögnin gefa pví tækifæri til að greina tengsl milli orlofsnýtingar og umönnunarpátttöku foreldra. Mynd 4 sýnir að hlutfall foreldra barna fædd 2014, sem sögðu móður vera megin umönnunaraðilann, lækkar eftir pví sem barnið verður eldra, en næstum öll prjú fyrstu æviárin er hlutfallið hæst í peim tilvikum par sem faðir hafði ekki fengið greiðslur úr Fæðingarorlofssjóði. Gögnin gefa pví tilefni til að álykta að feður sem nýta fæðingarorlof taki meiri pátt í umönnun barna sinna eftir að fæðingarorlofi lýkur en feður sem ekki nýta fæðingarorlof. ${ }^{1}$

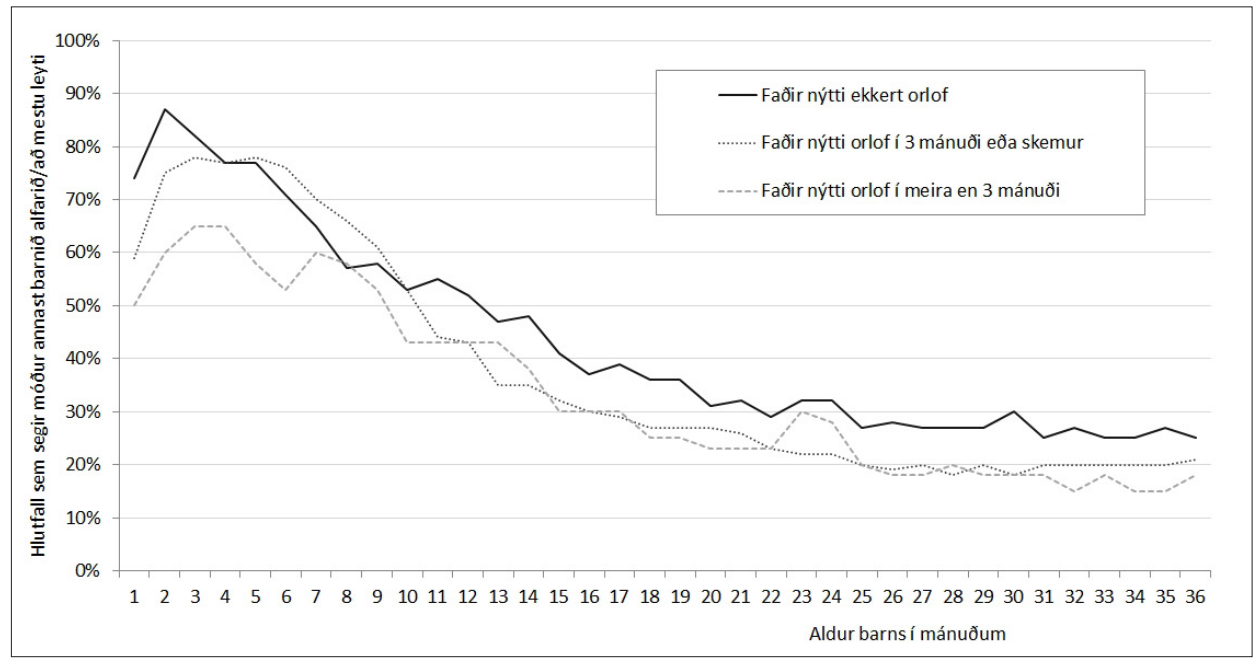

Mynd 4. Hlutfall foreldra sem áttu sitt fyrsta barn árið 2014 sem sögðu móður annast barnið alfarið eða að mestu leyti, greint eftir orlofsnýtingu föður - Foreldrar í sambúð/hjónabandi sem ekki eignuđust annað barn á rannsóknartímabilinu

Af ofantöldu má ráða að breytingar á umönnunarpátttöku foreldra, í kjölfar lagasetningar, hafa verið í samræmi við markmið laganna um að tryggja börnum samvistir við báða foreldra. Prátt fyrir aukna pátttöku feðra er móðirin pó megin umönnunaraðilinn fyrstu mánuðina og pví ljóst að gera má enn betur.

\subsection{Samræming fjölskyldu- og atvinnulífs}

Aukið jafnræði milli foreldra 1 umönnun barns ætti að auka möguleika mæðra til pátttöku á vinnumarkaði. Í könnununum var spurt um atvinnupátttöku og vinnutíma. Mynd 
5 sýnir hlutfall foreldra í vinnu árið fyrir fæðingu barns og premur árum eftir barnsfæðingu. Niðurstöður sýna að fæðing barns hefur mun meiri áhrif á atvinnupátttöku mæðra en feðra. Í fyrstu könnuninni munaði ekki miklu á atvinnupátttöku karla og kvenna árið áður en pau urðu foreldrar. Yfir 80\% karla og um 75\% kvenna voru í launuðu starfi á pessu tímabili. Mánuði eftir fæðingu var aftur á móti afar lítill hluti mæðranna í launuðu starfi en hið sama átti við um 60\% feðranna. Við priggja ára aldur barns voru 87\% feðra í launaðri vinnu sem er álíka hátt hlutfall og hafði verið í vinnu árið fyrir fæðingu. Hið sama átti við um einungis 60\% mæðra sem sýnir að mæður skiluðu sér mun síður aftur út á vinnumarkaðinn eftir barnsfæðingu en feður. Með árunum hefur dregið úr muninum á hlutfalli mæðra og feðra á vinnumarkaði. Í könnuninni sem náði til foreldra sem áttu sitt fyrsta barn árið 2014 voru 87\% feðra í vinnu premur árum eftir fæðingu fyrsta barns en hlutfallið meðal mæðra var 75\%.

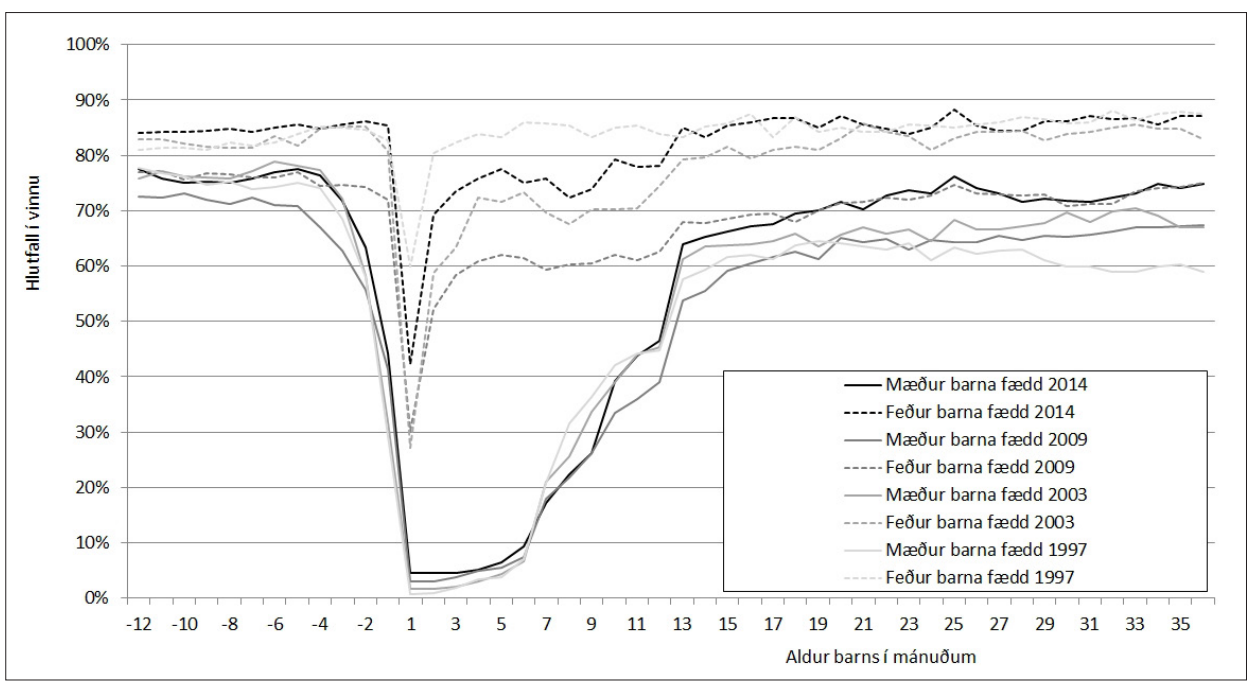

Mynd 5. Atvinnupátttaka foreldra sem áttu sitt fyrsta barn 1997, 2003, 2009 og 2014 - Foreldrar í sambúð/hjónabandi sem ekki eignuðust annað barn á rannsóknartímabilinu

Mynd 6 sýnir meðalvinnutíma mæðra og feðra. Hafa ber í huga að afar fá svör standa að baki meðalvinnutíma mæðra fyrstu mánuðina eftir fæðingu par sem mjög fáar mæður voru í vinnu á pví tímabili. Myndin sýnir að meðalvinnutími mæðra jókst á milli kannana en vinnutími feðra styttist. Til að mynda unnu feður, sem áttu sitt fyrsta barn árið 1997, um 47 klukkustundir á viku að meðaltali pegar barnið var á öðru og priðja ári en til samanburðar unnu feður barna fædd árið 2014 um 43 stundir á viku að meðaltali. Enn vinna feður pó lengri vinnudag en mæður. Dessar niðurstöður eru í samræmi við almenna próun á vinnumarkaði, par sem dregið hefur saman með vinnutíma karla og kvenna. 
Mynd 6 sýnir einnig að töluverðar breytingar hafa orðið á meðalvinnutíma mæðra fyrir og eftir fæðingu barns á tímabilinu. Í fyrstu könnuninni, sem náði til foreldra sem áttu sitt fyrsta barn árið 1997, unnu konurnar 40 klukkustunda vinnuviku að meðaltali ári fyrir fæðingu barnsins. Ári eftir fæðingu, unnu pær einungis 23 klukkustundir á viku, að meðaltali, sem sýnir að pað dró verulega úr fjölda vinnustunda eftir fæðingu barnsins. Áhrif barnsfæðingar á meðalfjölda vinnustunda var mun minni meðal mæðra sem áttu barn eftir að fæðingarorlofslögin tóku gildi árið 2000, og meðal mæðra sem áttu sitt fyrsta barn árið 2014 var lítill sem enginn munur á pví hvað mæðurnar unnu margar vinnustundir á viku fyrir fæðingu og eftir að barnið náði eins og hálfs árs aldri.

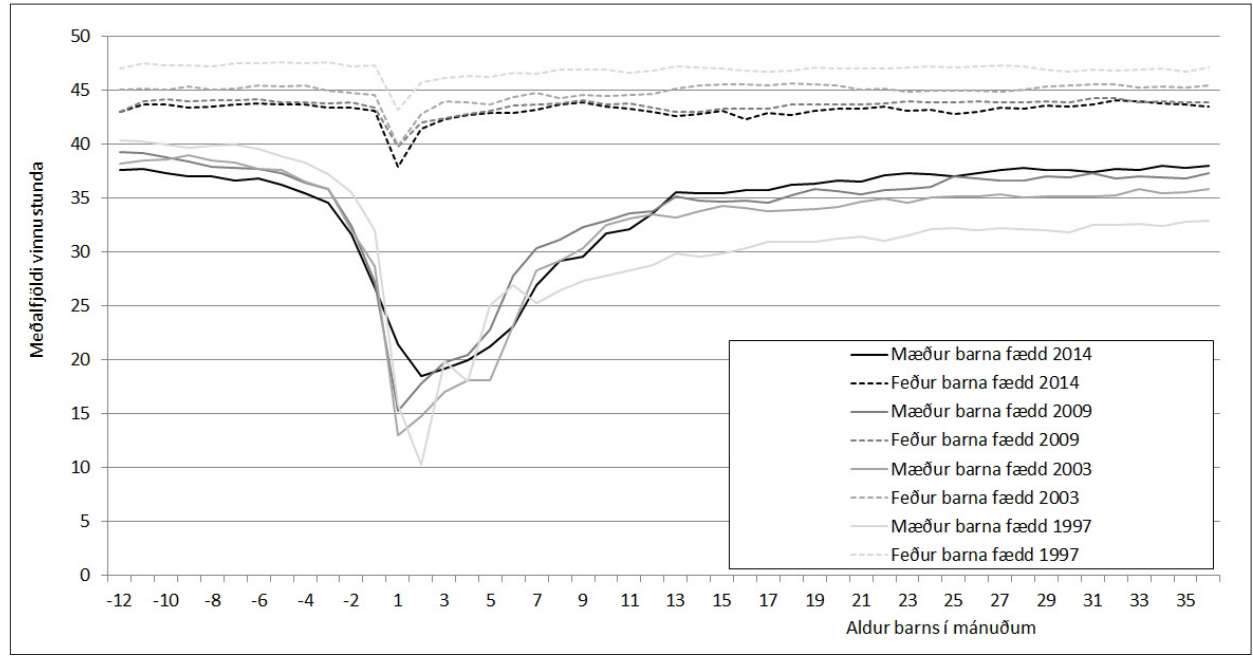

Mynd 6. Međalfjöldi vinnustunda foreldra sem áttu sitt fyrsta barn 1997, 2003, 2009 og 2014 - Foreldrar í sambúð/hjónabandi sem ekki eignuđust annað barn á rannsóknartímabilinu

Í könnununum voru foreldrar einnig spurðir hvort peir æettu alltaf, stundum, sjaldan eða aldrei auðvelt með að samræma vinnu og umönnun barns. Mynd 7 sýnir að hlutfall mæðra sem áttu alltaf auðvelt með að samræma vinnu og umönnun barns lækkaði milli fyrstu tveggja kannananna. Pessa breytingu á afstöðu mæðranna má líklega rekja til pess að meðalfjöldi vinnustunda var hærri hjá mæðrum sem áttu börn 2003 borið saman við mæður sem áttu fyrsta barn 1997. Á hinn bóginn hefur hlutfall feðra, sem eiga alltaf auðvelt með að samræma vinnu og umönnun barns, hækkað með árunum, á sama tíma og vinnutími karla hefur styst. 


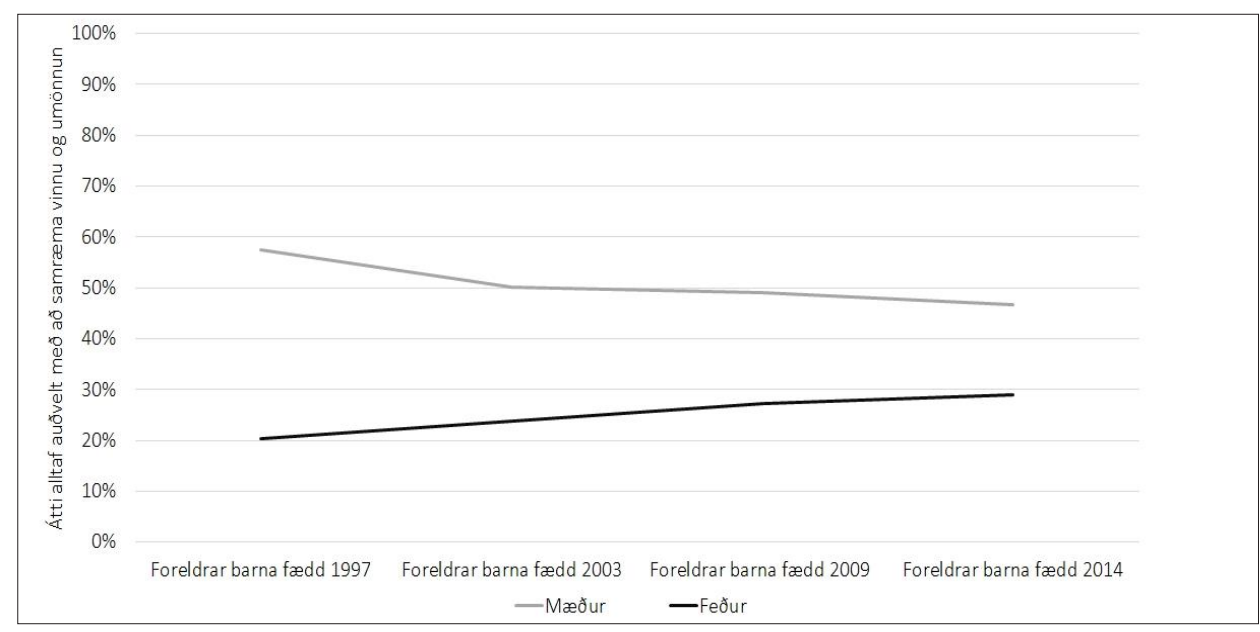

Mynd 7. Hlutfall foreldra barna fædd 1997, 2003, 2009 og 2014 sem áttu alltaf auðvelt með að samræma vinnu og umönnun barns

Af ofantöldu má ráða að miklar breytingar hafa orðið á atvinnupátttöku foreldra og umönnun barna eftir að lög um fæðingar- og foreldraorlof tóku gildi árið 2000. Á sama tíma og feður hafa aukið hlut sinn í umönnun barna sinna, hafa mæður aukið pátttöku sína á vinnumarkaði. Á pví 20 ára tímabili sem rannsóknin nær til, hefur sömuleiðis dregið saman með mæðrum og feðrum hvað pað varðar að eiga auðvelt með að samræma vinnu og umönnun barns.

\subsection{Umönnun barna skilgreinir möguleika mæðra - ekki feðra}

prátt fyrir að mikið hafi áunnist frá pví lög um fæðingar- og foreldraorlof tóku gildi árið 2000, er enn töluverður munur á stöðu mæðra og feðra. Eins og fram kemur að ofan, vinna mæður enn styttri vinnudag en feður og pær eru einnig megin umönnunaraðilinn fyrsta árið eftir fæðingu barns. Ísland greinir sig frá hinum Norðurlöndunum hvað pað varðar að hérlendis er foreldrum sjálfum ætlað að brúa bilið frá pví að fæðingarorlofi lýkur og par til leikskólar geta tekið við. Annars staðar er réttur barns til leikskóladvalar frá tilteknum aldri lögbundinn. Hérlendis hefur víða, og ekki síst á höfuðborgarsvæðinu, verið viðvarandi skortur á leikskólarýmum og foreldrar purft að brúa bilið frá pví að fæðingarorlofi lýkur og par til barn fær inni á leikskóla. Mynd 8 sýnir hlutfall foreldra sem sögðu barnið vera á leikskóla eða hjá dagforeldri fyrstu prjú æviárin. Eins og sjá má á myndinni, byrjuðu börn foreldranna í rannsókninni oft ekki í leikskóla fyrr en við tveggja ára aldur. Hlutfall barna á leikskólum hefur pó vaxið frá efnahagshruni. 


\section{STJÓRNSÝSLA}

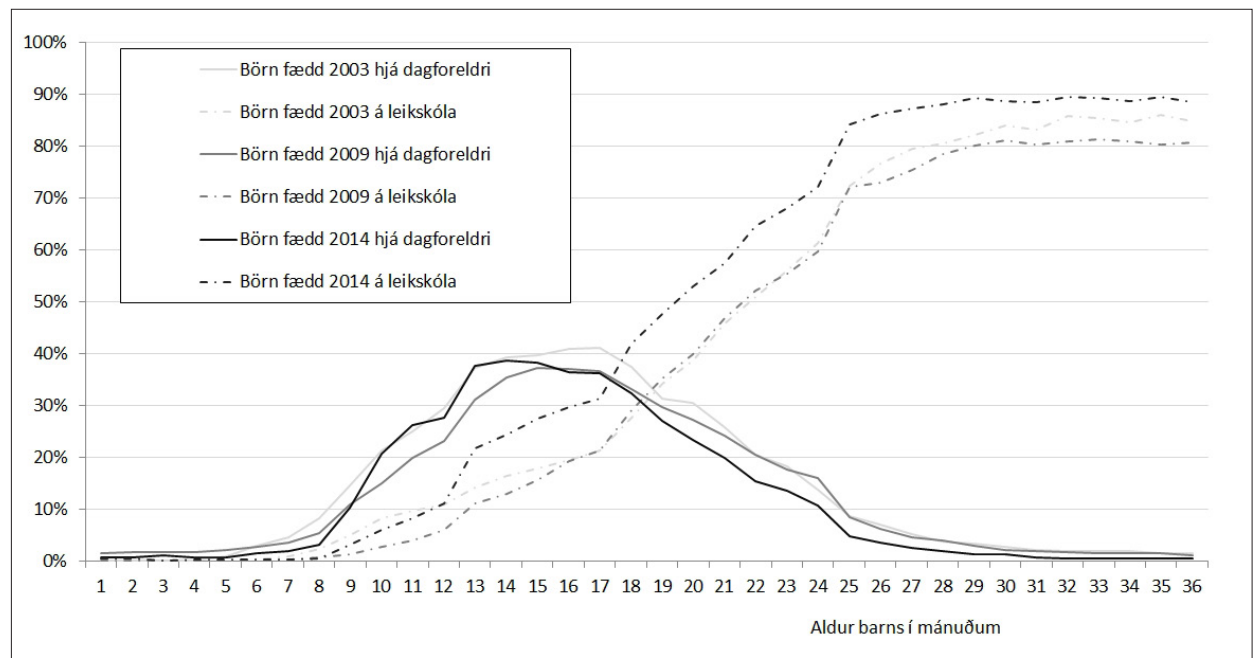

Mynd 8. Hlutfall barna hjá dagforeldri og í leikskóla - Börn foreldra í sambúđ/ hjónabandi með eitt barn fætt 2003, 2009 og 2014

Foreldrar brúa bilið milli fæðingarorlofs og leikskóla með ýmsum hætti. Dagforeldrar eru ein lausn, en innan við 40\% foreldra nýttu pjónustu dagforeldra í premur sîðustu könnununum (sjá mynd 8), og aðstoð ættingja er önnur leið. Pegar hins vegar er gripið til pess ráðs að breyta vinnumarkaðspátttöku til að brúa bilið eru pað mun fleiri mæður en feður sem slíkt gera. Mynd 9 sýnir hlutfall foreldra í fæðingarorlofi fyrstu 18 mánuðina eftir fæðingu barns. Athygli vekur að prátt fyrir að foreldrar sem tóku pátt 1 könnununum hafi samtals átt rétt á níu mánaða fæðingarorlofi, var töluverður hluti mæðra 1 fæðingarorlofi fyrsta árið. Detta bendir til að nokkuð stór hópur mæðra hafi lengt tímann heima með barninu með pví að vera í hlutaorlofi og að petta hlutfall hafi aukist milli kannana. 


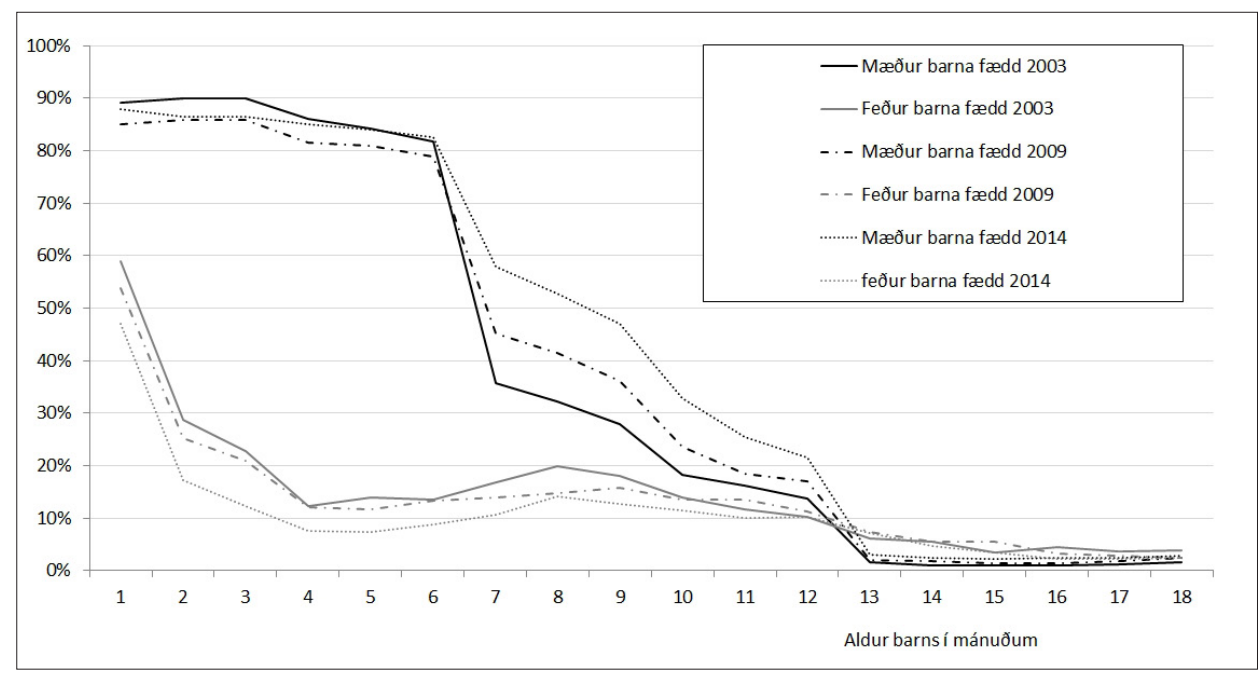

Mynd 9. Hlutfall foreldra í fæđingarorlofi (ýmist fullu orlofi eđa hlutaorlofi) Foreldrar í sambúd/hjónabandi međ eitt barn fætt 2003, 2009 og 2014

Fyrri heimildir hafa fjallað um hvernig hlutfall mæðra, sem voru frá vinnu 12 til 24 mánuðum eftir fæðingu barns, jókst eftir efnahagshrun. Mæður barna sem fæddust í efnahagskreppu voru líklegri til að lengja tímann heima með barninu en pær sem eignuðust barn fimm árum fyrir efnahagshrun. Lengingunni náðu pær með hlutaorlofi, notkun sumarleyfisdaga og með pví að taka launalaust leyfi. Höfundar skýrðu petta með pví að á sama tíma dró verulega úr orlofsnýtingu feðra og að pað hafi fallið í hlut mæðra að annast barnið pegar feður sáu sér ekki fært að nýta orlofið (Arnalds o.fl. 2019). Pað er pví óhætt að slá pví föstu að umönnunarbil, hvort heldur pað stafar af lítilli eða engri pátttöku feðra eða skorti á leikskólarýmum, er brúað af mæðrum með takmörkun á vinnumarkaðspátttöku peirra. Pannig skilgreinir umönnun barna svigrúm mæðra til atvinnupátttöku en ekki feðra. Augljóslega vinnur petta bil pví gegn pví markmiði laga um fæðingar- og foreldraorlof að gera báðum foreldrum kleift að samræma fjölskyldu- og atvinnulíf.

\section{Umræða um niðurstöður}

Samkvæmt Luetjens o.fl. (2019) er opinber stefna árangursrík ef hún veldur samfélagslegum breytingum sem almennt eru taldar vera til góðs, pegar almennt er viðurkennt að stjórnvöld eigi að beita sér í málaflokknum og pegar greina má langtímastuðning og -árangur. Ljóst er að lög um fæðingar- og foreldraorlof (nr. 95/2000) nutu víðtæks stuðnings almennings, hagsmunaaðila og stjórnmálamanna, enda höfðu kvennahreyfingar og stéttarfélög beitt sér fyrir breytingum á fæðingarorlofslöggjöfinni um nokkurt skeið. Lögin voru sampykkt mótatkvæðalaust á Alpingi og um pau ríkti pverpólitísk samstaða. Í greininni er árangur lagasetningarinnar pó fyrst og fremst metinn út frá samfélagslegum áhrifum hennar. Var petta gert með pví að birta niðurstöður fjögurra 
kannana um hvernig foreldrar hafa hagað atvinnupátttöku og umönnun barns fyrstu prjú æviárin auk pess að vísa í tölfræðigögn Fæðingarorlofssjóðs og fyrri rannsóknir.

pegar litið er til peirra breytinga sem lögin höfðu í för með sér, pá virðast lögin hafa pokað íslensku samfélagi í pá átt sem löggjafinn ætlaðist til, p.e. að auka töku feðra á fæðingarorlofi. Fyrir lagasetninguna var afar fátítt að feður tækju fæðingarorlof en undangengin 20 ár hafa um 85\% feðra nýtt sér réttinn til orlofs. Pannig hefur óframseljanlegur réttur til feðra hvatt pá til töku fæðingarorlofs og taka peir að meðaltali pann dagafjölda sem aðeins peir geta nýtt. Petta er í samræmi við reynslu víða um heim en pó sérstaklega á Norðurlöndum. Engum kemur á óvart að svo til hver einasta móðir nýtir rétt sinn og tekur pann tíma sem einungis hún getur tekið og oftast nýta mæður einnig pá mánuði sem hafa verið til skiptanna sem er í fullu samræmi við reynslu annarra samfélaga.

Markmiðssetning laganna var tvípætt, að tryggja barni samvistir við báða foreldra og gera foreldrum kleift að samræma fjölskyldu- og atvinnulíf. Niðurstöður endurtekinna kannana meðal foreldra sýna að lögin hafa haft umtalsverð áhrif í pá átt að jafna hlut foreldra við umönnun barna sinna. Hlutdeild feðra í umönnun barna sinna fyrstu prjú árin eftir fæðingu jókst mikið eftir að lögin tóku að fullu gildi og eykst við hverja mælingu. Niðurstöður rannsókna á trausti ungmenna til foreldra sinna benda eindregið í sömu átt (Arnarsson o.fl. 2019) og pá benda niðurstöður um lækkun á skilnaðartíðni (Olafsson \& Steingrimsdottir 2020) til pess að aukin pátttaka feðra heimafyrir hafi orðið til pess að auka samvinnu og samstöðu foreldra.

Niðurstöður sýna einnig að á peim 20 árum sem liðin eru frá pví lög um fæðingar og foreldraorlof (nr. 95/2000) tóku gildi hefur dregið saman með foreldrum hvað varðar atvinnupátttöku og fjölda vinnustunda sem ætti að auka líkur á pví að ekki pyki sjálfgefið að mæður fórni stöðu sinni á atvinnumarkaði frekar en feður. Pá sýna niðurstöður að eftir lagasetninguna árið 2000 snúa mæður fyrr aftur á vinnumarkaðinn eftir fæðingu og ná fyrr upp í pann vinnutímafjölda sem pær voru í fyrir barneignina. Athygli vekur að eftir lagasetninguna lækkaði hlutfall mæðra sem áttu alltaf auðvelt með að samræma vinnu og umönnun barns. Pannig virðist aukin atvinnupátttaka mæðra hafa gert peim erfiðara að samræma vinnu og fjölskyldulíf. Á sama tíma hefur hlutfall feðra sem eiga auðvelt með að samræma vinnu og fjölskyldulíf aukist jafnt og pétt, í takt við að meðalfjöldi vinnustunda peirra hefur lækkað. Pannig hafa möguleikar feðra til að samræma vinnu og fjölskyldulíf aukist, eftir gildistöku laganna, en aðrar samfélagslegar breytingar, auk fæðingarorlofslöggjafarinnar, hafa pó vafalítið haft áhrif á pá próun.

Umönnunarbilið sem verið hefur til staðar á Íslandi, bilið frá pví að fæðingarorlofi lýkur og par til leikskólar taka við, hefur pó orðið til pess að draga úr jöfnunaráhrifum fæðingarorlofsins. Niðurstöður sýna að pegar foreldrar reyna að brúa pað bil með pví að draga úr launavinnu, pá eru pað frekar mæðurnar sem fara pá leið. Pær miklu skerðingar sem urðu á greiðslum í fæðingarorlofi í kjölfar bankahrunsins 2008 drógu einnig úr jöfnunaráhrifum laganna, ekki aðeins sökum pess að færri feður nýttu rétt sinn til fæðingarorlofs og tóku færri daga, heldur einnig sökum pess að mæður lengdu enn frekar tímann heima með barninu (Arnalds o.fl. 2019). Pannig hefur umönnunarbilið grafið undan seinni markmiðssetningu laganna um að auðvelda foreldrum að sameina vinnu 
og fjölskyldulíf. Рað virðist pví óhætt að fullyrða að lögin hafi haft pau áhrif að dregið hafi saman í stöðu kynjanna á Íslandi, bæði hvað varðar fjölskyldulíf og atvinnulíf en að enn skilgreini umönnun barna möguleika mæðra frekar en feðra.

\section{Aftanmálsgrein}

1 Höfundar undirbúa um pessar mundir rannsókn á stöðu peirra feðra sem ekki nýta fæðingarorlof.

\section{Heimildir}

Albert Snorrason og Halldóra Einarsdóttir (2000). „Réttarstaða barna“, Morgunblaðid, 18. nóvember.

Angelov, N., Johansson, P. og Lindahl, E. (2016). „Parenthood and the gender gap in pay“, Journal of Labor Economics 34(3), 545-579.

Arnalds, Á. A., Belope-Nguema, S., Eydal, G. B. og Fernández-Cornejo, J. A. (2021). „Constructing fatherhood in the North and South: Paid parental leave, work and care in Iceland and Spain“, Acta Sociologica 65(1), 86-102. doi: 10.1177/00016993211008517.

Arnalds, Á. A., Duvander, A. Z., Eydal, G. B. og Gíslason, I. V. (2019). „Constructing parenthood in times of crisis“, Journal of Family Studies 27(3), 420-435. doi: 10.1080/13229400.2019.164622

Arnarsson, Á. M., Potrebny, T., Torsheim, T. og Eriksson, C. (2019). „Time-trends in Nordic adolescents' communication with their parents", Nordisk välfärdsforskning / Nordic Welfare Research 4(2), 88-100.

Ársæll Arnarsson og Hermína Gunnpórsdóttir (2016). „Íslenskir feður - bestir í heimi?“, í Helga Ólafsdóttir og Thamar M. Hejstra (ritstj.), Djódarspegill-Rannsóknir i félags- og mannvísindum XVII (bls. 1-8). Reykjavík: Félagsvísindastofnun Háskóla Íslands. Sótt af: http://hdl.handle.net/1946/26371

Barnalög nr. 76/2003.

Blau, F. D. og Kahn, L. M. (2017). „The gender wage gap: Extent, trends, and explanations“, Journal of Economic Literature 55(3), 789-865.

Brandt, B. og Kvande, E. (2020). Designing parental leave policy- The Norway model and the changing face of fatherbood. Bristol: Policy Press.

Bryndís Jónsdóttir (2007). Upplifun foreldra á faðingarorlofi (óbirt MA ritgerð). Háskóli Íslands, Reykjavík.

Bünning, M. og Pollmann-Schult, M. (2016). „Family policies and father's working hours: Cross-national differences in the paternal labour supply“, Work, Employment and Society 30(2), 256-274. doi: $10.1177 / 0950017015578999$

Cools, S., Fiva, J. H. og Kirkebøen, L. J. (2015). „Causal effects of paternity leave on children and parents“, Scandinavian Journal of Economics 117(3), 801-828. doi: 10.1111/sjoe.12113

Duvander, A-Z., Ferrarini, T. og Thalberg, S. (2005). Swedish parental leave and gender equality. Acbievemets and reform challenges in a European perspective. Stokkhólmur: Institutet för Framtidsstudier.

Duvander, A-Z. og Jans, A-C. (2009). „Consequences of fathers' parental leave use: Evidence from Sweden“, í Finnish Yearbook of Population Research 2009 (bls. 49-62). Helsinki: Family Federation of Finland.

Duvander, A-Z. og Lammi-Taskula, J. (2011). „Paid parental leave“, í I. V. Gíslason og G. B. Eydal (ritstj.), Parental leave, childcare and gender equality in the Nordic countries (bls. 31-63). Kaupmannahöfn: Norræna ráðherranefndin.

Easton, D. (1953). The political system: An inquiry into the state of political science. New York: Alfred A. Knopf. Einarsdóttir, D. og Pétursdóttir, G. M. (2009). „From reluctance to fast track engineering“, í P. Moss og S. Kamerman (ritstj.), The Politics of Parental Leave Policies: Children, parenting, gender and the labour market (bls. 159-174). Bristol: Policy Press.

Ellingsæter, A. og Leira, A. (2006). Politicising parenthood in Scandinavia. Gender relations in welfare states. Bristol: Policy Press. 
Esping-Andersen, G. (1990). The three worlds of welfare capitalism. Princeton, New Jersey: Princeton University Press.

Evertsson M., Boye, K. og Erman, J. (2018). „Fathers on call - A study on the sharing of care work among parents in Sweden“, Demographic Research 39(2), 33-60. doi:10.4054/DemRes.2018.39.2

Eydal, G. B. og Gíslason, I. V. (2014). „Caring fathers and parental leave in prosperous times and times of crisis: The case of Iceland“, í G. B. Eydal og T. Rostgaard: Fatherhood in the Nordic welfare states: Comparing care policies and practice (bls. 327-348). Bristol: Policy Press.

Eydal, G. B. og Gíslason, I. V. (2008). „Paid parental leave in Iceland - history and context“, í G. B. Eydal og I. V. Gíslason (ritstj.), Equal rights to earn and care. Parental leave in Iceland (bls. 15-44). Reykjavík: Félagsvísindastofnun Háskóla Íslands.

Eydal, G. B. og Rostgaard, T. (2012). „Towards a Nordic childcare policy: The political processes and agendas", í I. V. Gíslason og G. B. Eydal (ritsti.) Parental leave, childcare and gender equality in the Nordic countries (bls. 147-178). Kaupmannahöfn: Norræna ráðherranefndin.

Eydal, G. B., Rostgaard, T. og Hiilamo, H. T. (2018). „Family policies in the Nordic countries: Aiming at equality“, 1 G. B. Eydal og T. Rostgaard (ritstj.), Handbook of family policy (bls. 195-208). Cheltenham: Edward Elgar.

Fæðingarorlofssjóður. (e.d.). Óbirtar upplýsingar frá Fąðingarorlofssjóȯi.

Gallup (2003). Jafnrétti, viðhorfsrannsókn. Reykjavík: Gallup.

Gallup (2006). Viðhorfsrannsókn. Reykjavík: Gallup.

Hagstofa Íslands (2001). Vinnumarkaðsrannsókn. Reykjavík: Hagstofa Íslands.

Héðinn Unnsteinsson og Pétur Berg Matthíasson (2012). „Stefnumótun og áætlanagerð ráðuneyta: Leiðir að einföldun og samhæfingu“, Stjórnmál \& stjórnsýsla 1(8), 153-172.

Hough, M., Jackson, J., Bradford, B., Myhill, A. og Quinton, P. (2010). „Procedural justice, trust, and institutional legitimacy“. Policing 4(3), 203-210.

Ingólfur V. Gíslason (2005). „Feður sem taka lengra fæðingarorlof“", í Úlfar Hauksson (ritstj.), Rannsóknir i félagsvísindum VI (bls. 293-304). Reykjavík: Félagsvísindastofnun Háskóla Íslands.

Ingólfur V. Gíslason (2007). Faðingar- og foreldraorlof á Íslandi. Dróun eftir lagasetninguna árið 2000. Sótt af: https://www.jafnretti.is/static/files/utgefid_efni_af_gomlu_sidu/fadingarorlofsskyrsla.pdf

Inchley, J., Currie, D., Budisavljevic, S., Torsheim, T., Jastad, A., Cosma, A., Kelly, C. og Arnarsson, A. M. (2020). Spotlight on adolescent health and well-being: Findings from the 2017/18 Health Behaviour in School-aged Children (HBSC) Survey in Europe and Canada. Volume 1: Key findings. Kaupmannahöfn: World Health Organization.

Kahn, J. R., Garcia-Manglano, J. og Bianchi, S. M. (2014). „The motherhood penalty at midlife: Longterm effects of children on women's careers", Journal of Marriage and Family 76(1), 56-72.

Kitterød, R. H. (2013). „Mer familiearbeid og mindre job blant småbarnsfedre“, í B. Brandth og E. Kvande (ritstj.), Fedrekvoten og den farsvennlige velferdsstaten (bls. 42-58). Óslo: Universitetsforlaget.

Kleven, H. J., Landais, C., Posch, J., Steinhauer, A. og Zweimüller, J. (2019). „Child penalties across countries: Evidence and explanations“, AEA Papers and Proceedings 109, 122-126.

Kluve, J. og Tamm, M. (2013). „Parental leave regulations, mothers‘ labor force attachment and fathers childcare involvement: Evidence from a natural experiment", Journal of Population Economics 26, 9831005.

Koslowski, A., Blum, S., Dobrotić, I., Kaufman, G. og Moss, P. (2021). 17th international review of leave policies and related research 2021. Sótt af: www.leavenetwork.org/annual-review-reports/review-2021/

Kotsadam, A. og Finseraas, H. (2011). „The state intervenes in the battle of the sexes: Causal effects of paternity leave“, Social Science Research 40(6), 1611-1622. doi: 10.1016/j.ssresearch.2011.06.011

Lammi-Taskula, J. (2017). „Fathers on leave alone in Finland: Negotiations and lived experiences“, í M. O’Brien og K. Wall (ritstj.), Comparative perspectives on work-life balance and gender equality (bls. 89-106). New York:SpringerOpen. Sóttaf: https://link.springer.com/content/pdf/10.1007\%2F978-3-319-42970-0. pdf 
Lappegård, T., Duvander, A-Z., Neyer, G., Viklund, I., Andersen, S. N. og Garðarsdóttir, Ó. (2020). „Fathers" use of parental leave and union dissolution“, European Journal of Population 36(1), 1-25. doi: 101007/s10680-019-09518-z

Lasswell, H. (1956). The decision process: Seven categories of functional analysis. College Park, Md: University of Maryland.

Lárusdóttir, I. D., Eydal, G. B. og Arnalds, Á. A. (væntanleg). Shared care among parents living apart. Óbirt handrit.

Luetjens, J., Mintrom, M. og 't Hart, P. (ritsti.) (2019). Successful public policy: Lessons from Australia and New Zealand. Canberra: ANZSOG.

Lög um breytingu á lagaákvæðum er varða réttarstöðu samkynhneigðra nr. 65/2006.

Lög um breytingu á lögum nr. 95/2000, um fæðingar- og foreldraorlof nr. 75/2008.

Lög um breytingu á lögum nr. 95/2000, um fæðingar- og foreldraorlof nr. 143/2012.

Lög um breytingu á lögum um fæðingar- og foreldraorlof, nr. 95/2000, með síðari breytingum nr. $149 / 2019$

Lög um breytingu á nokkrum lögum á sviði sifjaréttar nr. 69/2006.

Lög um breytingu á ýmsum lögum vegna laga um kynrænt sjálfræði nr. 153/2020.

Lög um breytingu lagaákvæða um fæðingarorlof nr. 147/1997.

Lög um fæðingar- og foreldraorlof $\mathrm{nr}$. 95/2000.

Lög um fæðingar- og foreldraorlof nr. 144/2020.

Lög um samning Sameinuðu pjóðanna um réttindi barnsins nr. 19/2013.

Lög um ýmsar forsendur frumvarps til fjárlaga fyrir árið 2014 nr. 140/2013.

McConnel, A. (2010). Understanding policy success: Retbinking public policy. Basingstoke: Palgrave Macmillan.

Moss, P. (2015). 11th international review of leave policies and research 2015. Sótt af: http://www.leavenetwork.org/fileadmin/Leavenetwork/Annual_reviews/2015_full_review3_final_8july.pdf

Moss, P., Duvander, A-Z. og Koslowski, A. (2019). „Introduction: much work still to do“, í P. Moss, A. Koslowski og A-Z. Duvander (ritstj.), Parental leave and beyond. Recent international developments, current issues and future directions (bls. 1-20). Bristol: Policy Press.

Nefnd um efnahagsleg völd kvenna (2004). Efnahagsleg völd kvenna. Sótt af: https:/ /www.stjornarradid.is/ media/forsaetisraduneyti-media/media/efnhasleg_vold_kvenna/evkskyrsla.pdf

Nieuwenhuis, R., Need, A. og Van der Kolk, H. (2017). „Is there such a thing as too long childcare leave?", International Journal of Sociology and Social Policy 37, 2-15.

Olafsson, A. og Steingrimsdottir, H. (2019). „How does daddy at home affect marital stability?“, The Economic Journal 130(629), 1471-1500. doi: 10.1093/ej/ueaa009

Olivetti, C. og Petrongolo, B. (2016). „The evolution of gender gaps in industrialized countries“, Annual Review of Economics 8, 405-434.

Osborne, S. (2006). „The new public governance?“, Public Management Review 8(3), 377-387. doi: $10.1080 / 14719030600853022$

Ólafsson, S., Daly, M., Kangas, O. og Palme, J. (ritsti.) (2019). Welfare and the great recession. A comparative study. Oxford: Oxford University Press.

Rege, M. og Solli, I. F. (2013). „The impact of paternity leave on fathers' future earnings“, Demograpby $50,2255-2277$.

Rostgaard, T. og Lausten, M. (2014). „The coming and going of the father's quota in Denmark: Consequences for fathers' parental leave take-up“, í G. B. Eydal og T. Rostgaard (ritsti.), Fatherhood in the Nordic welfare states: Comparing care policies and practice (bls. 277-302). Bristol: Policy Press.

Sarkadi, A., Kristiansson, R., Oberklaid, F. og Bremberg, S. (2008). „Fathers' involvement and children's developmental outcomes: A systematic review of longitudinal studies“, Acta Paediatrica 97(2), 153158. doi: $10.1111 /$ j.1651-2227.2007.00572

Schober, P. S. (2014). „Parental leave and domestic work of mothers and fathers: A longitudinal study of two reforms in west Germany“, Journal of Social Policy 43(2), 351-372. doi: 10.1017/ S0047279413000809 
Sigríður Andersen og Soffía Kristín Dórðardóttir (2000). „Hverjir hagnast á breytingum á fæðingarorlofi??", Morgunbladid, 3. maí.

Sigrún Júlíusdóttir og Sólveg Sigurðardóttir (2013). Eftir skilnað: Um foreldrasamstarf og kynslódasamskipti. Reykjavík: Háskólaútgáfan og Rannsóknastofnun í barna- og fjölskylduvernd.

Sigurðardóttir, H. M. og Garðarsdóttir, Ó. (2018). „Backlash in gender eqality? Fathers` parental leave during a time of economic crisis“, Journal of European Social Policy 28(4), 342-356. doi: $10.1177 / 0958928717739243$

Stefnuyfirlýsing ríkisstjórnar (1999). Sótt af: https://www.stjornarradid.is/rikisstjorn/sogulegt-efni/ um-rikisstjorn/1999/05/28/Stefnuyfirlysing-rikisstjornar-1999/

Stefnuyfirlýsing ríkisstjórnar (2007). Sótt af: https://www.stjornarradid.is/rikisstjorn/sogulegt-efni/ um-rikisstjorn/2007/05/23/Stefnuyfirlysing-rikisstjornar-2007/

Stefnuyfirlýsing ríkisstjórnar (2017). Sótt af: https://www.stjornarradid.is/rikisstjorn/stefnuyfirlysing/

Thévenon, O. (2011). „Family policies in OECD countries: A comparative analysis“, Population and development review 37(1), 57-87.

„VR skoðar að greiða full laun í fæðingarorlofi“. (200). Morgunblaðið, 15. júní.

pingfundur nr. 104/2000. Fadingar- og foreldraorlof. Sótt af: https://www.althingi.is/altext/125/04/ r28141426.sgml

Dingskjal nr. 1502/2017-2021. Tillaga til pingsáatlunar um fjölskyldustefnu fyrir árin 2017-2021 með áhershu á börn og fjölskyldur.

Dingskjal nr. 1230/1996-1997. Dingsályktun um mótun opinberrar fjölskyldustefnu og adgerdir til að styrkja stödu fjölskyldunnar. 
